\title{
Will the "Nexus" Requirement of Apple v. Samsung Preclude Injunctive Relief in the Majority of Patent Cases?: Echoes of the Entire Market Value Rule
}

\author{
DANIEL HARRIS BREAN*
}

\begin{abstract}
* C 2014 Daniel Harris Brean. Daniel Harris Brean is an intellectual property attorney at The Webb Law Firm in Pittsburgh, PA, where he works primarily on patent litigation matters relating to computer network systems and online commerce technology. He also has considerable expertise in the area of industrial design protection and design patents, frequently publishing and speaking on these topics. Dan is a former law clerk to the Honorable Jimmie V. Reyna at the United States Court of Appeals for the Federal Circuit. He graduated in 2005 from Carnegie Mellon University with a B.S. in Physics and received his J.D. cum laude in 2008 from the University of Pittsburgh School of Law, where he received the Faculty Award for Excellence in Legal Scholarship and the ABA-BNA Intellectual Property Law Award. He is also an adjunct professor, teaching patent law, at the University of Pittsburgh School of Law.

Mr. Brean wishes to express his sincere gratitude to those who helped build the foundation for and improve this Article. This Article benefited greatly from conversations with Christopher V. Carani of McAndrews, Held \& Malloy, J. Derek McCorquindale of Finnegan, and many of Mr. Brean's colleagues at The Webb Law Firm, particularly Christian D. Ehret, whose feedback on earlier drafts of this piece was invaluable. The views and opinions expressed in this Article, as well as any errors, are solely those of the Author and should not be attributed to The Webb Law Firm or any of its clientele. Questions and comments are welcome to dbrean@webblaw.com.
\end{abstract}




\section{TABLE OF CONTENTS}

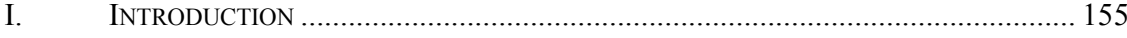

II. APPLE I: PRELIMINARY InJUNCTION PROCEEDINGS AND THE

ORIGIN OF THE “NEXUS” REQUIREMENT ........................................................ 158

A. District Court Proceedings .................................................................. 158

1. The District Court's Basis for the Nexus Requirement ..................... 161

B. Federal Circuit Proceedings.............................................................. 162

1. The Federal Circuit's Basis for the Nexus Requirement ................... 163

2. Policy Concerns Behind the Federal Circuit Decision: Judge Bryson's Hypothetical Questioning During

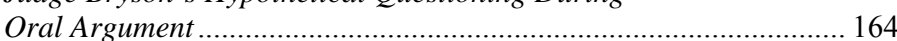

III. APPLE II: SOLIDIFYING AND CLARIFYING THE NEXUS REQUIREMENT ................... 165

IV. How the NeXus Requirement Echoes the Entire Market

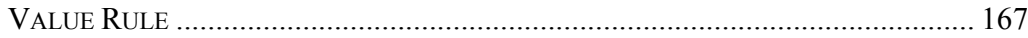

A. The Entire Market Value Rule …......................................................... 168

B. The "Nexus" Between Injunctions and Damages ...................................... 171

V. POST-APPLE I AND APPLE II INJUNCTION RULINGS ............................................ 172

A. Brocade Completely Disregards Apple I and Apple II in

Entering a Permanent Injunction......................................................... 172

B. LifeScan Draws a Line Between Inventions that Are Single

Features of Complex Products and Inventions that Are a

"Substantial Part" of a Product.....

C. Douglas Dynamics Reverses a Denial of a Permanent

Injunction with No Reference to Apple I or Apple II.............................. 176

VI. APPLE III: PERMANENT INJUNCTION PROCEEDINGS ............................................ 178

A. District Court Proceedings .................................................................... 178

B. Apple's Position on Appeal to the Federal Circuit ................................ 184

1. The Propriety of a Nexus Requirement for

Permanent Injunctions ...................................................................... 184

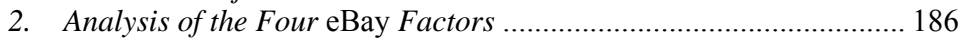

3. Application of the Nexus Requirement ............................................ 188

4. Appropriately Tailoring Injunctions when the Nexus Requirement Is Not Satisfied................................................ 189

C. Potential Ways To Resolve the Nexus Issue ................................................ 190

1. When and How Does the Nexus Requirement Apply to Permanent Injunctions?...

2. Is the Nexus Issue Better Considered Under eBay

Factors Three and Four?

3. Must the Nexus Requirement Be Analyzed on a

Patent-by-Patent Basis?

4. What Evidence Suffices To Show Nexus?.............................................. 197

5. Can an Appropriately Tailored Injunction with a "Sunset Provision" Strike the Correct Equitable Balance?...

VII. The APPle III Federal Circuit Panel Decision Paves the

WAY FOR EN BANC CONSIDERATION OF THE NEXUS ISSUE.................................. 203

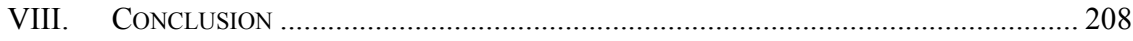




\section{INTRODUCTION}

In the past, when a patent owner proved infringement, it was effectively presumed that the harm to the patentee was irreparable and that the infringing conduct should be enjoined. This practice was viewed as appropriate because a patent provides only the right to "exclude others" from making, using, selling, offering to sell, or importing the patented invention - essentially, the right to protect one's market exclusivity or market share. ${ }^{1}$ The Supreme Court put a stop to this practice in eBay Inc. v. MercExchange, LL.C., where it held that "the decision whether to grant or deny injunctive relief ... must be exercised consistent with traditional principles of equity," which includes consideration of whether the plaintiff "has suffered an irreparable injury" and whether "remedies available at law ... are inadequate to compensate for that injury.",

EBay, by requiring consideration and balancing of various equitable factors, made injunctions considerably more difficult to obtain than under the "general rule" "that a permanent injunction will issue once infringement and validity have been adjudged" that was previously applied by the Federal Circuit. ${ }^{3}$ Post-eBay, patentees that do not participate in the market for their own inventions are unlikely to be irreparably harmed by infringement.

1. See 35 U.S.C. $\S 154$ (2006) ("Every patent shall . . grant to the patentee ... the right to exclude others from making, using, offering for sale, or selling the invention throughout the United States ...." (emphasis added)); id. § 283 ("The several courts having jurisdiction of cases under this title may grant injunctions in accordance with the principles of equity to prevent the violation of any right secured by patent, on such terms as the court deems reasonable." (emphasis added)); see also U.S. Const. art I., § 8., cl. 8 (providing that Congress shall have the power "[t]o promote the Progress of Science and useful Arts, by securing for limited Times to Authors and Inventors the exclusive Right to their respective Writings and Discoveries" (emphasis added)).

2. 547 U.S. 388, 391, 394 (2006). The eBay Court expressed the four-factor test as follows:

According to well-established principles of equity, a plaintiff seeking a permanent injunction must satisfy a four factor test before a court may grant such relief. A plaintiff must demonstrate: (1) that it has suffered an irreparable injury; (2) that remedies available at law, such as monetary damages, are inadequate to compensate for that injury; (3) that, considering the balance of hardships between the plaintiff and defendant, a remedy in equity is warranted; and (4) that Id. at 391 .

the public interest would not be disserved by a permanent injunction.

3. Id. at 393-94 (stating that the Federal Circuit "Court of Appeals [erred in] depart[ing] in the opposite direction from the four-factor test" for permanent injunctive relief in patent cases) (quoting MercExchange, L.L.C. v. eBay, Inc., 401 F.3d 1323, 1338 (Fed. Cir. 2005), vacated, 547 U.S. 388 (2006))) (internal quotation marks omitted). 
Indeed, Justice Kennedy, joined by Justices Stevens, Souter, and Breyer, wrote separately in eBay to make the point that injunctions may not be appropriate "[where] firms use patents not as a basis for producing and selling goods but, instead, primarily for obtaining licensing fees."

A market-participating patentee's loss of market share, however, remained a viable way to prove irreparable harm post-eBay. ${ }^{5}$ The Federal Circuit has made clear that "even though a successful patent infringement plaintiff can no longer rely on presumptions or other short-cuts to support a request for a permanent injunction, it does not follow that courts should entirely ignore the fundamental nature of patents as property rights granting the owner the right to exclude."6 The court still recognized a patentee's loss of market share to an infringer in direct competition with the patentee as all but requiring an injunction.?

But now this avenue to injunctive relief has been severely curtailed. In Apple, Inc. v. Samsung Electronics Co. (Apple I), ${ }^{8}$ the Federal Circuit endorsed a "nexus" requirement for determining whether a patent owner has suffered irreparable harm of lost market share as a result of infringement. ${ }^{9}$ This new hurdle to injunctive relief, which the court borrowed from analogous damages law, will likely prove exceedingly difficult to satisfy where a patented feature comprises only a portion of a

4. Id. at 396-97 (Kennedy, J., concurring). Justice Kennedy was expressing his concern about cases involving patentees that are nonpracticing entities - particularly the relatively new "industry" of so-called "patent trolls"- that are aggressively enforcing patents and had been leveraging the possibility of injunctive relief to extort unreasonably high settlement license fees. Id.; see also z4 Techs., Inc. v. Microsoft Corp., 434 F. Supp. 2d 437, 441 (E.D. Tex. 2006) (justifying the conclusion that monetary damages sufficiently compensated the patent holder based on Justice Kennedy's concurrence in eBay).

5. See, e.g., i4i Ltd. P'ship v. Microsoft Corp., 598 F.3d 831, 861-62 (Fed. Cir. 2010) ("Past harm to a patentee's market share, revenues, and brand recognition is relevant for determining whether the patentee 'has suffered an irreparable injury.' ... In this case, the district court properly considered strong circumstantial evidence that Microsoft's infringement rendered i4i's product obsolete for much of the custom XML market, causing i4i to lose market share and change its business strategy to survive." (emphasis omitted) (quoting eBay, 547 U.S. at 391)), aff'd, 131 S. Ct. 2238 (2011).

6. Robert Bosch LLC v. Pylon Mfg. Corp., 659 F.3d 1142, 1149 (Fed. Cir. 2011).

7. Id. at 1150-51 ("[T]he [district] court committed a clear error of judgment when it concluded that Bosch failed to demonstrate irreparable harm in the face of overwhelming evidence to the contrary. This is particularly true in light of Bosch's evidence of: (1) the parties' direct competition; (2) loss in market share and access to potential customers resulting from Pylon's introduction of infringing beam blades; and (3) Pylon's lack of financial wherewithal to satisfy a judgment. Given these facts, there is 'no basis on which the district court rationally could have' concluded that Bosch failed to show irreparable harm."

8. $\quad 678$ F.3d 1314 (Fed. Cir. 2012).

9. Id. at 1324 . 
larger accused product. Because most patents are not directed to entire products or systems but only a portion thereof, the nexus requirement would likely preclude injunctive relief in the vast majority of cases. Some particularly vulnerable cases are those involving technologies such as consumer electronics, software, telecommunications, heavy machinery, robotics, logistics, and transportation, all of which tend to involve complex multifaceted products and systems.

Part II of this Article discusses the Apple I preliminary injunction proceedings and explores how the nexus requirement came to be announced and applied. It demonstrates that legitimate policy concerns appear to have motivated the creation of the nexus requirement, which insists that patentees satisfy a high burden of proving that the patented feature drives the demand for the infringing product in order to demonstrate irreparable harm redressable via an injunction. Part III discusses a subsequent appealApple II - of another preliminary injunction decision in the Apple $v$. Samsung case and explains how the nexus requirement was clarified to be satisfied only with affirmative proof of nexus, not proof that the absence of a feature would somehow diminish demand or value. Part IV explains the entire market value rule precedent for patent infringement damages and juxtaposes it with the nexus requirement. It shows that the Apple I and Apple II decisions adopt concepts and verbiage from the entire market value rule cases, which preclude patentees from collecting damages based on an entire multicomponent product unless it can be shown that the patented feature drives the consumer demand for the entire product-a very high burden that is rarely satisfied. Part V looks at injunction decisions subsequent to Apple I to see how courts have applied the nexus requirement in other cases and shows that where the equities suggest an injunction is appropriate, courts are finding ways to skirt or even ignore the nexus requirement. Part VI follows the proceedings in the Apple v. Samsung case concerning Apple's request for and the denial of permanent injunctive relief following the findings of infringement by Samsung, including Apple's third appeal to the Federal Circuit surrounding the nexus issue. Part VI also includes a discussion of advisable ways to relax the rigidness and potential inequity of the nexus test by, for example, (1) recasting the way that nexus considerations are analyzed under eBay by addressing them outside the context of irreparable harm; (2) allowing nexus to be considered in the aggregate where multiple patents are infringed by a single product; and (3) encouraging more flexible injunctions to be entered that enjoin only the infringing features and allow time for those features 
to be designed around before the injunction goes into effect. Part VII briefly considers the panel decision in the Apple III appeal, showing that the decision is inconsistent with the prior Apple nexus decisions, leaving the nexus issue for en banc consideration. Part VIII concludes.

\section{APPLE I: PRELIMINARY INJUNCTION PROCEEDINGS AND THE ORIGIN OF THE "NEXUS" REQUIREMENT}

This Part will discuss the background of the litigation between Apple and Samsung through the preliminary injunction phase of the case. It explains the preliminary injunction determinations for Apple's various patents as they relate to the new "nexus" requirement for proving irreparable harm. The origin, cited legal support, and apparent policy considerations for the nexus requirement are addressed.

\section{A. District Court Proceedings}

Apple and Samsung have long been involved in massive high-profile litigation surrounding Apple's patents covering its ubiquitous iPad and iPhone products. ${ }^{10}$ The following are representative figures of the design patents-in-suit, alongside some of the Samsung accused products.
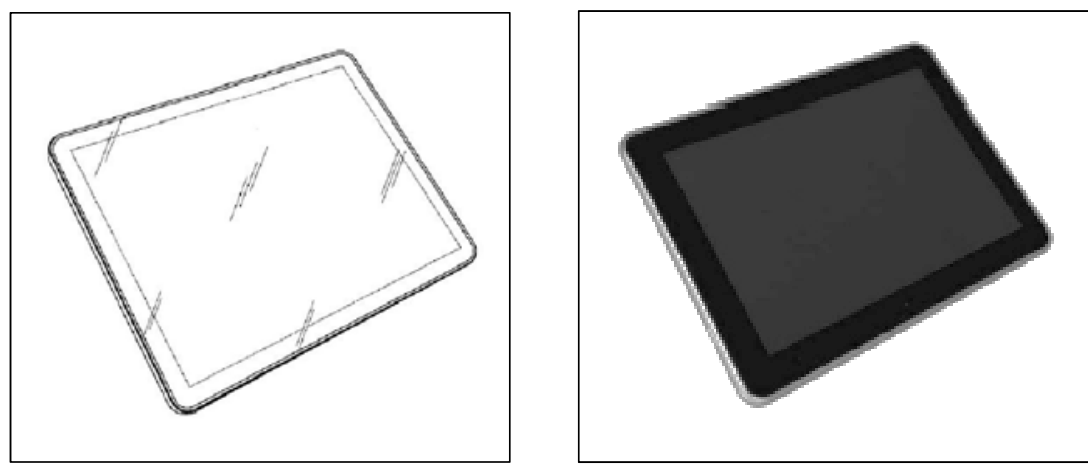

U.S. PATENT No. D504,889 / SAMSUNG GALAXY TAB 10.1 ${ }^{11}$

10. See, e.g., Apple, Inc. v. Samsung Elecs. Co., No. 11-CV-01846-LHK, 2011 WL 7036077 (N.D. Cal. Dec. 2, 2011), aff'd in part, vacated in part, 678 F.3d 1314.

11. Id. at $* 1-2$. 


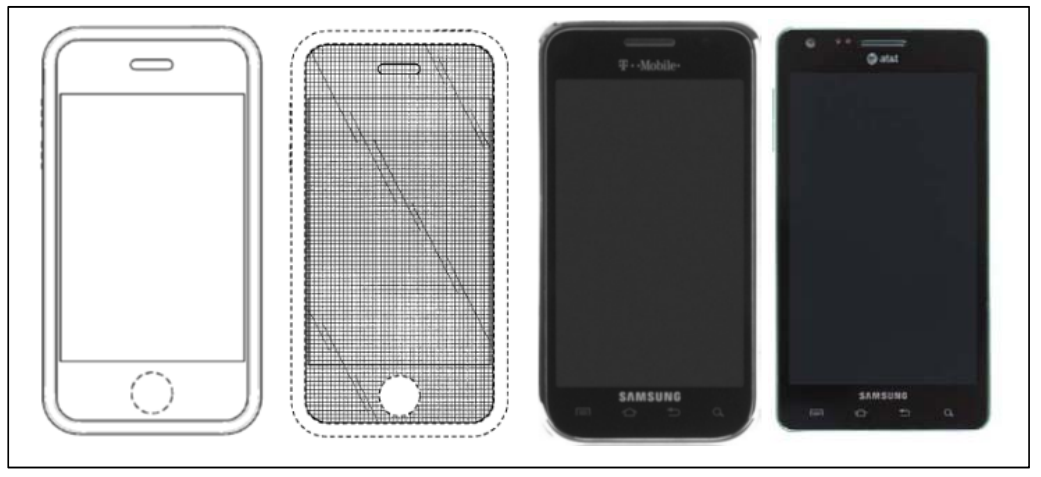

U.S. PATENT Nos. D593,087 \& D618,667/

SAMSUNG GALAXY S 4G \& INFUSE 4G ${ }^{12}$

Additionally, Apple asserted a design patent covering a graphical user interface for its iPhone products. ${ }^{13}$

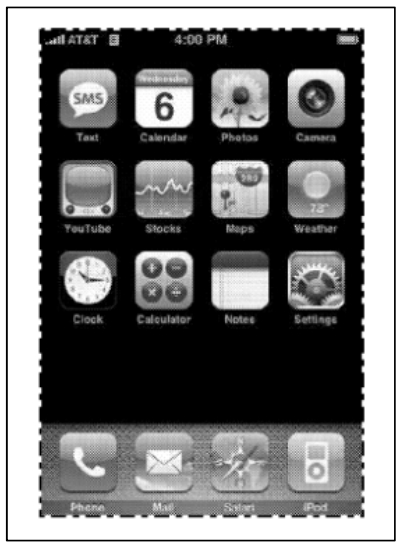

U.S. PATENT No. D604,305

12. Id. at *1-2, 17 .

13. See Apple, Inc. v. Samsung Elecs. Co. (Apple III Dist.), 909 F. Supp. 2d 1147, 1151 (N.D. Cal. 2012), rev'd, 727 F.3d 1214 (Fed. Cir. 2013); U.S. Patent No. D604,305 S (filed Nov. 17, 2009). 
Apple also asserted utility patents against Samsung that covered various user interface features of its products' touch screens. These patents included U.S. Patent No. 7,469,381, which covers a software feature where a user of a smartphone scrolls past the end of a document and the document appears to "bounce back"; U.S. Patent No. 7,844,915, which covers multitouch gestures, for example, when a user can "pinch to zoom" and enlarge a document or image on a screen; and U.S. Patent No. $7,864,163$, which covers the ability for a user to "double-tap to zoom," that is, center and enlarge a portion of an image or document by doubletapping the desired area with the user's finger. ${ }^{14}$

Apple moved for a preliminary injunction at the district court before Judge Lucy Koh, contending that Apple's designs were innovative and distinctive and that Samsung's sales of infringing smartphones and tablets caused irreparable harm to Apple in the form of, inter alia, lost market share. ${ }^{15}$ Apple emphasized that it and Samsung were in direct competition for customers and that sales of smartphones and tablets have long-term downstream effects on subsequent smartphone and tablet purchases due to customers' desires to maintain compatibility with previous purchases of software and accessories. ${ }^{16}$ Particularly in the tablet market, where Apple and Samsung together dominated the industry, it was clear "that a sale to Samsung translate[d] to a lost sale to Apple." 17

The district court denied Apple's motion regarding the '889 (iPad) and '087 (iPhone) patents due to validity-related issues, which prevented a finding of a likelihood of success on the merits. ${ }^{18}$ Although the district court found the '667 (iPhone) patent likely valid and infringed, the district court denied Apple's request for a preliminary injunction because Apple failed to establish a "nexus" between Apple's loss of market share and Samsung's alleged infringement. ${ }^{19}$ In particular,

[t]he [district] court found that despite Apple's evidence that "product design generally is at least one factor, and for some people may be the primary factor, influencing a person's decision to purchase a smartphone," other evidence indicated that the "driver in consumer demand may be the novelty of the product, and not necessarily the design," and that "smartphone buyers are motivated to purchase products for a whole host of reasons." 20

14. See Apple I, 678 F.3d at 1318; Amended Complaint at 7-8, Apple, $2011 \mathrm{WL}$ 7036077.

15. See Apple I, 678 F.3d at 1320.

16. See id. at $1320,1336-37$.

17. Id. at 1336 .

18. Id. at 1319-22.

19. Id. at 1321.

20. Id. (emphasis added). 
Thus, Apple's motion for a preliminary injunction was denied with respect to the '667 (iPhone) patent as well. Interestingly, the district court noted that "design mattered more to consumers in tablets than in smartphones." 21

As to the utility patent directed to the bounce-back software feature, the district court again denied Apple's motion for a preliminary injunction, finding no proof of nexus because "Apple has neither alleged, nor established, that the ' 381 patent is either necessary to, or a core functionality of, the products that it seeks to enjoin. Nor has Apple shown that consumers' purchasing decisions are based on the existence of a snap back feature protected by the '381 patent."22

\title{
1. The District Court's Basis for the Nexus Requirement
}

Judge Koh explained the basis for the nexus requirement as follows:

\begin{abstract}
In addition to showing injury, Apple must establish a nexus between Apple's harm of lost customers and loss in market share and Samsung's allegedly infringing conduct. See Quad/Tech, Inc. v. Q.I. Press Controls B. V., 701 F. Supp. 2d 644, 657 (E.D. Pa. 2010) ("Quad/Tech has failed to prove a causal relation between alleged loss and alleged infringement, which is necessary to prove irreparable harm, and it failed to prove lost sales arising from the Defendants' alleged sale of a markless registration control system."); z4 Techs., Inc. v. Microsoft Corp., 434 F. Supp. 2d 437, 440-41 (E.D. Tex. 2006) (finding no irreparable harm in part because "it is not likely that any consumer of Microsoft's Windows or Office software purchases these products for their product activation functionality"); $c f$. i4i, 598 F.3d at 861 (upholding district court's conclusion that "i4i was irreparably injured by Microsoft's infringement, based on its factual findings that Microsoft and $\mathrm{i} 4 \mathrm{i}$ were direct competitors in the custom XML market, and that i4i lost market share as a result of the infringing Word products") (emphasis added); Perfect 10, Inc. v. Google, Inc., 653 F.3d 976, 981-82 (9th Cir. 2011) (holding that there must be a causal connection between the violation and the harm alleged in order to establish irreparable harm in copyright infringement case). ${ }^{23}$
\end{abstract}

The cases cited by Judge Koh in this passage are inapposite, nonbinding, and do not support any such nexus requirement, however. In Quad/Tech,

21. Id.

22. Apple, Inc. v. Samsung Elecs. Co., No. 11-CV-01846-LHK, 2011 WL 7036077, at $* 39$ (N.D. Cal. Dec. 2, 2011).

23. Id. at $* 20$. 
there was no showing of infringement, so nexus was not in issue. ${ }^{24}$ The quoted statement in $i 4 i$ was speaking about loss of market share "as a result of the infringing Word products," not the infringing XML feature. ${ }^{25}$ Perfect 10 was a copyright case where there was no evidence that the lost revenues had anything to do with Google's alleged infringement of Perfect 10's images. ${ }^{26}$ Lastly, z4 Technologies involved a finding of no irreparable harm primarily because "Microsoft's continued infringement does not inhibit z4's ability to market, sell, or license its patented technology to other entities in the market." 27 The denial of an injunction hinged on z4's inability to prove lost sales of the infringing software functionality. Specifically, the court found that "Microsoft does not produce product activation software that it then individually sells, distributes, or licenses to other software manufacturers or consumers. If it did, then z4 might suffer irreparable harm in that Microsoft would be excluding z4 from selling or licensing its technology to those software manufacturers or consumers." 28 Thus, when the court noted that "Microsoft only uses the infringing technology as a small component of its own software, and it is not likely that any consumer of Microsoft's Windows or Office software purchases these products for their product activation functionality," it was merely observing one reason why $\mathrm{z} 4$ failed to show lost sales, not imposing any sort of nexus requirement. ${ }^{29}$

Judge Koh thus seems to have cut the nexus requirement from whole cloth or at least made some very liberal inferences when reading the case law. To have said that Apple "must" establish a nexus to prove irreparable harm clearly started down a new path of injunction jurisprudence.

\section{B. Federal Circuit Proceedings}

On appeal, the Federal Circuit endorsed the district court's requirement of a nexus between the alleged infringement and loss of market share, holding that

24. See Quad/Tech, Inc. v. Q.I. Press Controls B.V., 701 F. Supp. 2d 644, 656-57 (E.D. Pa. 2010), aff'd 413 F. App'x 278 (Fed. Cir. 2011) ("Quad/Tech's non-use of the patent is an important consideration against a finding of irreparable harm.").

25. i4i Ltd. P'ship v. Microsoft Corp., 598 F.3d 831, 861 (Fed. Cir. 2010) (emphasis added).

26. Perfect 10, Inc. v. Google, Inc., 653 F.3d 976, 981-82 (9th Cir. 2011) (explaining that "search engines other than Google contribute to making Perfect 10 images freely available" and that "notwithstanding Perfect 10's theory of irreparable harm, it failed to submit a statement from even a single former subscriber who ceased paying for Perfect 10 's service because of the content freely available via Google").

27. z4 Techs., Inc. v. Microsoft Corp., 434 F. Supp. 2d 437, 440 (E.D. Tex. 2006).

28. Id.

29. Id. 
[t]o show irreparable harm, it is necessary to show that the infringement caused harm in the first place. Sales lost to an infringing product cannot irreparably harm a patentee if consumers buy that product for reasons other than the patented feature. If the patented feature does not drive the demand for the product, sales would be lost even if the offending feature were absent from the accused product. Thus, a likelihood of irreparable harm cannot be shown if sales would be lost regardless of the infringing conduct. ${ }^{30}$

Ultimately, the Federal Circuit found that the nexus requirement was not met with respect to the ' 667 or ' $087^{31}$ (iPhone) patents, finding no abuse of discretion by the district court because substantial evidence was presented on both sides of the issue. ${ }^{32}$ The Federal Circuit deemed the nexus requirement satisfied with respect to the $' 889^{33}$ (iPad) patent, emphasizing the district court's finding that design was more important to tablet purchasers than smartphone purchasers and also the fact that "the tablet market appeared to be dominated by only two manufacturers, Apple and Samsung, who together controlled a substantial share of the market." ${ }^{34}$

As to the bounce-back utility patent - the only utility patent at issue in the appeal - the Federal Circuit summarily affirmed the district court's conclusion that the evidence was inadequate to prove "that consumer purchasing decisions were based on the presence of the bounce-back feature." 35

\section{The Federal Circuit's Basis for the Nexus Requirement}

The Federal Circuit in Apple I justified its endorsement of the district court's nexus requirement as follows:

[A] likelihood of irreparable harm cannot be shown if sales would be lost regardless of the infringing conduct. See Voda v. Cordis Corp., 536 F.3d 1311, 1329 (Fed. Cir. 2008) (explaining that "the district court did not clearly err in finding that [the plaintiff] failed to show that [the defendant's] infringement caused him irreparable injury" (emphasis in original)); Procter \& Gamble Co. v. Ultreo, Inc., 574 F. Supp. 2d 339, 349 (S.D.N.Y. 2008) (in trademark context,

30. Apple I, 678 F.3d 1314, 1324 (Fed. Cir. 2012) (emphasis added).

31. The Apple I court reached the irreparable harm analysis with respect to the '087 patent because it reversed the district court's finding that this patent was likely anticipated. Id. at 1327.

32. Id. at $1324 \&$ n.3, 1327.

33. The Apple I court reached the irreparable harm analysis with respect to the ' 889 patent because it reversed the district court's finding that this patent was likely obvious. Id. at 1332 .

34. Id. at $1321,1328$.

35. Id. at 1327. 
finding no "nexus between allegedly false advertising and lost sales" and concluding that "[s]uch a loss, absent a nexus or a logical connection to false advertising, is insufficient to demonstrate the irreparable harm required to issue a preliminary injunction").

A mere showing that Apple might lose some insubstantial market share as a result of Samsung's infringement is not enough. As the Supreme Court has pointed out, a party seeking injunctive relief must make "a clear showing" that it is at risk of irreparable harm, Winter, 555 U.S. at 22, 129 S. Ct. 365, which entails showing "a likelihood of substantial and immediate irreparable injury," $O$ 'Shea v. Littleton, 414 U.S. 488, 502, 94 S. Ct. 669, 38 L.Ed.2d 674 (1974). See Weinberger v. Romero-Barcelo, 456 U.S. 305, 311, 102 S. Ct. 1798, 72 L.Ed.2d 91 (1982) (holding that an injunction should not issue as a matter of course for irreparable harm that is "merely trifling"). Given our deferential standard of review, we are not prepared to overturn the district court's finding that Apple failed to satisfy its burden of establishing the likelihood of irreparable harm. ${ }^{36}$

As with the district court, the authority cited by the Federal Circuit is inapposite and nonbinding on the nexus issue. Voda involved a denial of an injunction because the plaintiff could show only that the infringement caused harm "to his exclusive licensee, rather than himself." 37 Thus, "[the plaintiff] failed to show that [the defendant's] infringement caused him irreparable injury." 38 Whether the infringement was the cause of the harm was not at issue. Procter \& Gamble was a district court trademark case. $^{39}$ Finally, the Supreme Court cases cited simply stand for the proposition that one must show clear entitlement to injunctive relief with Strong evidence of irreparable harm. Thus, the Federal Circuit's endorsement of the nexus requirement simply follows the new path blazed by Judge Koh.

\section{Policy Concerns Behind the Federal Circuit Decision: Judge Bryson's Hypothetical Questioning During Oral Argument}

Judge Bryson, the author of the Apple I opinion, questioned the parties' counsel during oral argument with his oft-utilized hypothetical scenarios. ${ }^{40}$ Specifically, Judge Bryson asked Apple’s counsel,

36. Id. at $1324-25$

37. Voda v. Cordis Corp., 536 F.3d 1311, 1329 (Fed. Cir. 2008).

38. Id. 2008).

39. Procter \& Gamble Co. v. Ultreo, Inc., 574 F. Supp. 2d 339, 349-50 (S.D.N.Y.

40. Oral Argument, Apple I, 678 F.3d 1314 (No. 2012-1105), available at http:// oralarguments.cafc.uscourts.gov/default.aspx?fl=2012-1105.mp3. 
Suppose that Chrysler really likes the spiffy design of Ford's cup holders in the back seat of their Focus and they copy them. Blatantly copy them. Let's say ... no consumer buys a Chrysler because those cup holder designs really are nifty. You wouldn't enter an injunction under those circumstances, would you?

$\ldots$

[Y] ou can say that any sales that were lost carry with them all sorts of additional losses that are incalculable - market share, loyalty, dilution, those kinds of things - that are really difficult to calculate. And that would be irreparable harm if there were any sales that were lost, but since there weren't any [in my hypothetical] then it seems to me very hard to say that is irreparable harm within the meaning of the four-part test for injunctions.

If you say the accused product is the whole Chrysler, there may have been purchases ... because Chrysler has neat ads or because they have a new engine. That does not seem to me to be irreparable harm of the sort that we're really focused on, which is irreparable harm from the act of infringement. You're saying as long as the product which incorporates the infringing feature is taking sales away from, in this case Ford, that's enough. Can that possibly be right?41

Although Apple's counsel attempted to shift the focus of Judge Bryson's hypothetical to the "balance of the hardships" and "public interest" factors, Judge Bryson insisted that the force of his analogy went to the irreparable harm prong of the injunction analysis. ${ }^{42}$ Thus, in Judge Bryson's mind, the issue seemed to be not whether it is fair or equitable to the parties or the public to enjoin the sale of an entire car over a patent covering a cup holder but whether the sale of the car can be deemed to irreparably harm the patent holder's market share absent proof that the infringing feature was the reason for the sale of the infringing car.

\section{APPLE II: SOLIDIFYING AND CLARIFYING THE NEXUS REQUIREMENT}

A few months after the Federal Circuit's decision in Apple I, the court had another opportunity to reconsider the nexus requirement. In Apple II, Apple separately asserted against Samsung U.S. Patent No. 8,086,604, which covers a unified search software feature, and sought to

41. Id. at 15:00-18:35.

42. Id. at 15:53-17:08. 
preliminarily enjoin Samsung's manufacture and sale of the Samsung Galaxy Nexus product. ${ }^{43}$

Apple's alleged evidence of nexus was largely based on the popular "Siri" search application in Apple's iPhones, which depends in part on the patented unified search features. ${ }^{44}$ Thus, Apple contended that "consumers must be at least in part attracted to the Galaxy Nexus because it too incorporates the unified search feature" of Apple's patent. ${ }^{45}$ The district court had found this reasoning persuasive of nexus because the patented unified search functionality was "core to Siri's functionality" and "a but-for driver of demand." 46 In reaching its conclusion, the district court held that "the requisite causal nexus can be established by showing either that the patented feature is an affirmative driver of consumer demand, or that its absence would suppress consumer demand."47 The district court also adopted Apple's argument "that a causal nexus may be established by showing that removing the patented features will diminish the value or substantially interfere with the functionality of the accused device." ${ }^{48}$ On this basis, the district court entered a preliminary injunction against Samsung. ${ }^{49}$

On appeal, the Federal Circuit reaffirmed the nexus requirement, confirming that

the causal nexus inquiry is indeed part of the irreparable harm calculus: it informs whether the patentee's allegations of irreparable harm are pertinent to the injunctive relief analysis, or whether the patentee seeks to leverage its patent for competitive gain beyond that which the inventive contribution and value of the patent warrant. ${ }^{50}$

Thus, "[t]he patentee must ... show that the infringing feature drives demand for the accused product.",51

However, the Federal Circuit rejected the district court's notion that nexus could be established by showing that the absence of the patented feature somehow diminished demand for or value of the infringing

43. Apple, Inc. v. Samsung Elecs. Co. (Apple II), 695 F.3d 1370, 1372-73 (Fed. Cir. 2012).

44. Id. at 1375 .

45. Id.

46. Id. at 1376 (quoting Apple, Inc. v. Samsung Elecs. Co, 877 F. Supp. 2d 838, 909 (N.D. Cal. 2012), rev'd, 695 F.3d 1370) (internal quotation marks omitted).

47. Id. at 1375 (quoting Apple, 877 F. Supp. 2d at 906) (internal quotation marks omitted).

48. Id. (citing Apple, 877 F. Supp. 2d at 905-06).

49. Id. at 1373.

50. Id. at 1375 .

51. Id. (citing Apple I, 678 F.3d 1314, 1324 (Fed. Cir. 2012)). 
product and reversed the entry of a preliminary injunction as a result. ${ }^{52}$ Taking issue with the district court's characterization of the law, the Federal Circuit clarified that

\begin{abstract}
[t]he causal nexus requirement is not satisfied simply because removing an allegedly infringing component would leave a particular feature, application, or device less valued or inoperable. A laptop computer, for example, will not work (or work long enough) without a battery, cooling fan, or even the screws that may hold its frame together, and its value would be accordingly depreciated should those components be removed. That does not mean, however, that every such component is "core" to the operation of the machine, let alone that each component is the driver of consumer demand. To establish a sufficiently strong causal nexus, Apple must show that consumers buy the Galaxy Nexus because it is equipped with the apparatus claimed in the ' 604 patent - not because it can search in general, and not even because it has unified search. 53
\end{abstract}

Following Apple II, two things were abundantly clear. First, the causal nexus requirement was indeed a "requirement" that "must" be satisfied for an injunction to be ordered. ${ }^{54}$ Second, it was clear that the patentee must affirmatively prove the patent drives demand for the infringing sale to satisfy the nexus requirement. Proving that the absence of a feature decreases demand does not suffice - the evidence must affirmatively show that the patented feature is the reason that customers buy the infringing product.

\title{
IV. How the NEXus REQUiREMENT ECHOES THE ENTIRE MARKET VALUE RULE
}

Whether intentionally, subconsciously, or coincidentally, the nexus requirement of Apple I and Apple II borrows concepts and language from the Federal Circuit's analogous jurisprudence pertaining to damages. By using loaded phrases such as "drive the demand for the product," the Federal Circuit has invoked its so-called entire market value rule precedent and opened the door for accused infringers to avoid injunctions in many cases that involve complex and multicomponent technology. This Part will explain the origin and framework of the entire market value rule, provide some examples of how the rule is applied, and juxtapose the entire market value rule's analysis and policy justifications with those of the nexus requirement. Although the district court and the Federal

52. Id. at 1376 .

53. Id. (emphasis added).

54. See id. 
Circuit have provided some citations to legal authority purporting to support the application of a nexus requirement for injunctions, this Article will show that the best and most correct source for the nexus requirement comes from the Federal Circuit's entire market value rule case law. Indeed, both damages and injunctive relief are ways to compensate a patentee for the harm caused by the infringement, and both areas of the law share similar concerns about how the harm should be appropriately remedied when the scope of the patented invention is small compared with the accused product.

\section{A. The Entire Market Value Rule}

Patent owners are entitled to compensatory damages upon a finding of infringement, with a "reasonable royalty" being the minimum damages to which a patentee is entitled. ${ }^{55}$ Where complex or multicomponent products are involved, it can be difficult to ascertain how large the royalty should be. This is because the particular magnitude and value of the contribution of a single component or feature within the grand scheme of a larger product can be obscured. There is a risk in such situations that a royalty calculated based on the entire product, for example, five percent of all sales revenues, would overvalue the patented feature's contribution and therefore overcompensate the patentee. The entire market value rule guards against such overcompensation by ensuring that where a patent covers only one component or feature of a larger product, damages awarded for infringement do not reach beyond the scope of the patented component or feature.

This rule traces back to the Supreme Court's decision in Garretson v. Clark, in which the Court noted the challenges and risks of basing damages on the entire market value of a product:

When a patent is for an improvement, and not for an entirely new machine or contrivance, the patentee must show in what particulars his improvement has added to the usefulness of the machine or contrivance. He must separate its results distinctly from those of the other parts, so that the benefits derived from it may be distinctly seen and appreciated. "The patentee" ... "must in every case give evidence tending to separate or apportion the defendant's profits and the patentee's damages between the patented feature and the unpatented features, and such evidence must be reliable and tangible, and not conjectural or speculative; or he must show, by equally reliable and satisfactory evidence, that the profits and damages are to be calculated on the whole machine, for the reason that the

55. 35 U.S.C. $§ 284$ (2006) ("Upon finding for the claimant the court shall award the claimant damages adequate to compensate for the infringement, but in no event less than a reasonable royalty for the use made of the invention by the infringer, together with interest and costs as fixed by the court."). 
entire value of the whole machine, as a marketable article, is properly and legally attributable to the patented feature." 56

In general, damages are to be calculated based on the "smallest salable patent-practicing unit," rather than the complete multicomponent product. ${ }^{57}$ For example, if the product accused of infringing is a laptop computer and the patent covers a laptop battery, a royalty of ten percent per battery is less likely to overcompensate the patentee because it is a fraction of the value of the battery alone, whereas a royalty of two percent per laptop carries a high risk of overcompensation because it is a fraction of the value of the laptop, which includes many features and functions other than its battery. Choosing the smaller component as the royalty base removes a great deal of subjectivity from the analysis.

The entire market value rule is "a narrow exception to this general rule." $" 58$ If it can be shown that "the patented [feature] 'was of such paramount importance that it substantially created the value of the component parts," a patentee may be awarded damages as a percentage of revenues or profits attributable to the entire multicomponent product. ${ }^{59}$ In other words, the patented feature must be "the "basis for customer demand" for the product as a whole. ${ }^{60}$

In Lucent Technologies, Inc. v. Gateway, Inc., the patent-in-suit was directed to a visual "date-picker" feature found in the calendar functionality of Microsoft's Outlook e-mail program. ${ }^{61}$ The Federal Circuit began by explaining that "[f]or the entire market value rule to apply, the patentee must prove that 'the patent-related feature is the basis for customer demand." 62 The court found that this case had a "lack of evidence demonstrating the patented method ... as the basis - or even a substantial basis - of the consumer demand for Outlook." ${ }^{\prime 63}$

56. 111 U.S. 120,121 (1884).

57. LaserDynamics, Inc. v. Quanta Computer, Inc., 694 F.3d 51, 67 (Fed. Cir. 2012) (quoting Cornell Univ. v. Hewlett-Packard Co., 609 F. Supp. 2d 279, 283, 287-88 (N.D.N.Y. 2009)) (internal quotation marks omitted).

58. Id.

59. Rite-Hite Corp. v. Kelley Co., 56 F.3d 1538, 1549, 1551 (Fed. Cir. 1995) (quoting Marconi Wireless Tel. Co. v. United States, 53 U.S.P.Q. 246, 250 (Ct. Cl. 1942), aff'd in part, vacated in part, 320 U.S. 1 (1943)).

60. Lucent Techs., Inc. v. Gateway, Inc., 580 F.3d 1301, 1336 (Fed. Cir. 2009) (quoting Rite-Hite, 56 F.3d at 1549).

61. Id. at $1317,1337-38$.

62. Id. at 1336 (quoting Rite-Hite, 56 F.3d at 1549).

63. Id. at 1337. 
$[\mathrm{T}]$ he only reasonable conclusion supported by the evidence is that the infringing use of the date-picker tool in Outlook is but a very small component of a much larger software program. The vast majority of the features, when used, do not infringe. The date-picker tool's minor role in the overall program is further confirmed when one considers the relative importance of certain other features, e.g., e-mail. Consistent with this description of Outlook, Lucent did not carry its evidentiary burden of proving that anyone purchased Outlook because of the patented method. Indeed, Lucent's damages expert conceded that there was no "evidence that anybody anywhere at any time ever bought Outlook, be it an equipment manufacturer or an individual consumer, ... . because it had a date picker." J.A 07821-22. And when we consider the importance of the many features not covered by the Day patent compared to the one infringing feature in Outlook, we can only arrive at the unmistakable conclusion that the invention described in claim 19 of the Day patent is not the reason consumers purchase Outlook. ${ }^{64}$

In LaserDynamics, Inc. v. Quanta Computer, Inc., the patent-in-suit was directed to a function of an optical disc drive (ODD) that allowed the drive to automatically distinguish between types of discs, for example, CD versus DVD. ${ }^{65}$ The patent owner sought damages as a percentage of the revenues from an entire infringing laptop computer, claiming that the patented disc drive feature "provided an important and valuable function that was present in all ODDs currently in use, and that the presence of this function was a prerequisite for any laptop computer to be successful in the marketplace." 66 The Federal Circuit held that the patentee could not claim damages as a percentage of each laptop computer because it failed to show that the patented ODD functionality "drove demand for the laptop computers." ${ }^{67}$ The court emphasized that

[i]t is not enough to merely show that the disc discrimination method is viewed as valuable, important, or even essential to the use of the laptop computer. Nor is it enough to show that a laptop computer without an ODD practicing the disc discrimination method would be commercially unviable. Were this sufficient, a plethora of features of a laptop computer could be deemed to drive demand for the entire product. To name a few, a high resolution screen, responsive keyboard, fast wireless network receiver, and extended-life battery are all in a sense important or essential features to a laptop computer; take away one of these features and consumers are unlikely to select such a laptop computer in the marketplace. But proof that consumers would not want a laptop computer without such features is not tantamount to proof that any one of those features alone drives the market for laptop computers. Put another way, if given a choice between two otherwise equivalent laptop computers, only one of which practices optical disc discrimination, proof that consumers would choose the laptop computer having the disc discrimination functionality says nothing as to

64. Id. at 1337-38 (emphasis added).

65. LaserDynamics, Inc. v. Quanta Computer, Inc., 694 F.3d 51, 56-57 (Fed. Cir. 2012).

66. Id. at 60 .

67. Id. at 68 . 
whether the presence of that functionality is what motivates consumers to buy a laptop computer in the first place. It is this latter and higher degree of proof that must exist to support an entire market value rule theory. ${ }^{68}$

As shown by the above summaries of Lucent and LaserDynamics, a plaintiff cannot invoke the entire market value rule without meeting an exceedingly high burden of proof. Cases that would find the rule satisfied are rare and must involve substantial evidence of consumer purchasing behavior. The end results of LaserDynamics and Lucent should not be surprising, though, because ordinarily sales of complex and multicomponent products will not be attributable to any single consumer-motivating feature. Rather than deny damages outright to the patentee in such situations, however, the patentee is simply compelled to accept a lesser and more appropriate valuation of the invention's contribution to the accused product.

\section{B. The "Nexus" Between Injunctions and Damages}

The close parallels between the nexus requirement for injunctions and the entire market value rule for damages are readily apparent. Both analytical frameworks require the patentee to prove that the patented feature "drives demand for the entire product" $"$ or "drives consumer demand for the accused product." 70

Indeed, both LaserDynamics and Apple II clarified the respective frameworks in the same way by requiring affirmative proof of nexus, not negative proof concerning the effects of the absence of a feature. LaserDynamics held that it is insufficient "to show that a laptop computer without an ODD practicing the disc discrimination method would be commercially unviable" and went on to explain that laptops contain many essential components such as batteries that are necessary for commercial viability but that this does not mean that battery "is what motivates consumers to buy a laptop computer in the first place.",71 Likewise, Apple II held that "[t]he causal nexus requirement is not satisfied simply because removing an allegedly infringing component would leave a particular feature, application, or device less valued or inoperable"

68. Id. (emphasis added).

69. Id. at 67.

70. Apple II, 695 F.3d 1370, 1375 (Fed. Cir. 2012) (citing Apple I, 678 F.3d 1314, 1324 (Fed. Cir. 2012)).

71. LaserDynamics, 694 F.3d at 68. 
and noted that even though a laptop computer will not work without, for example, a battery, "[t]hat does not mean, however, that every such component is "core' to the operation of the machine, let alone that each component is the driver of consumer demand."72

Oddly, despite the causal nexus and entire market value rule frameworks being nearly identical, neither Apple I nor Apple II cited a single entire market value rule case when announcing and refining the nexus requirement. It is unclear whether the absence of any cross-citation to the entire market value rule precedent is intentional, but the virtual identity between the frameworks suggests that the Federal Circuit was at least cognizant of the closely analogous precedent.

\section{POST-APPLE I AND APPLE II INJUNCTION RULINGS}

This Part examines applications of the nexus requirement following the Apple I and Apple II decisions. It shows that both district courts and the Federal Circuit appear reluctant to rigidly apply the nexus requirement where the equities otherwise indicate the presence of irreparable harm, particularly where the infringement is committed by the patentee's competitor and there is a resulting loss of sales.

\section{A. Brocade Completely Disregards Apple I and Apple II in Entering a Permanent Injunction}

The first district court case to apply the nexus requirement outside of the Apple litigation was Brocade Communications Systems v. A10 Networks, Inc. ${ }^{73}$ Brocade's patents-in-suit were directed to improvements in load balancing functionality for computer servers. ${ }^{74}$ Ultimately, the district court granted Brocade's request for a permanent injunction against A10's accused products despite a total absence of any proof of nexus. ${ }^{75}$

The district court began by reciting the nexus requirement from Apple $I$ and Apple II but immediately questioned whether the nexus requirement was appropriate in the permanent injunction context. ${ }^{76}$ It observed "a curious absence of references to the causal nexus standard" in the Federal Circuit's most recent decisions regarding permanent injunctions ${ }^{77}$ and noted that although the Federal Circuit had distinguished between preliminary and permanent injunctive relief in a recent trademark case as

72. Apple II, 695 F.3d at 1376.

73. See No. C 10-3428 PSG, 2013 WL 140039, at *2 (N.D. Cal. Jan. 10, 2013).

74. Id. at *1.

75. Id. at $* 8$.

76. Id. at $* 2-3$.

77. Id. at $* 3$. 
having "different prerequisites and serv[ing] entirely different purposes," "both the Supreme Court and the Federal Circuit have advised that the standard for irreparable harm is the same for preliminary and permanent injunctions." 79

Against this backdrop, the district court "confess[ed] to doubt that the causal nexus as articulated in Apple II should be required for all irreparable harms offered in support of a request for a permanent injunction." 80 The district court specifically disagreed with Judge Bryson's view that nexus is a better inquiry for the "balance of hardships" and "public interest" factors of the injunction analysis, ${ }^{81}$ saying, "Whatever its ultimate merit where the particular irreparable harm claimed is a loss of sales, that strict standard appears to move into the irreparable harm analysis a consideration better suited for the equitable factors of balance of hardships and public interest." 82

As to the merits of the case, the district court made clear at the outset that Brocade "has not shown that its patented features drove demand for either its sales or A10's sales." ${ }^{83}$ This is because

Brocade has not presented sufficient evidence to support its contention that its loss of market share and sales was the result of A10's infringement. Brocade asserts that GSLB and HA were critical features for both the ServerIron and AX products. But as A10 points out, Brocade does not hold the patents to GSLB or $\mathrm{HA}$; it owns only the patents to enhancements of those features. ${ }^{84}$

Thus, rather than dwell on the nexus issues, the district court emphasized the Federal Circuit's statements in Robert Bosch LLC v. Pylon Manufacturing Corp., that despite the post-eBay absence of a presumption in favor of injunctive relief against infringers, courts should not "entirely

78. Id. (quoting Lermer Ger. GmbH v. Lermer Corp., 94 F.3d 1575, 1577 (Fed. Cir. 1996) (internal quotation marks omitted). The court in Lermer had noted that "[b]ecause of the exacting standards that a party must meet to obtain a preliminary injunction, it frequently happens that a party is denied a preliminary injunction pending the disposition of the lawsuit but ultimately prevails on the merits and is awarded a permanent injunction as part of the final judgment in the case. The two instruments are distinct forms of equitable relief that have different prerequisites and serve entirely different purposes." 94 F.3d at 1577.

79. Brocade, $2013 \mathrm{WL} 140039$, at *3.

80. Id.

81. Id.; supra Part II.B.2.

82. Brocade, 2013 WL 140039, at*3.

83. Id. at $* 3$ n. 26 .

84. Id. 
ignore the fundamental nature of patents as property rights granting the owner the right to exclude." 85

The district court favorably cited and quoted post-Apple I and Apple II permanent injunction decisions for the propositions that (1) because "a patentee's right to exclude is a fundamental tenet of patent law ... absent adverse equitable considerations, the winner of a judgment of validity and infringement may normally expect to regain the exclusivity that was lost with the infringement" 86 and (2) "the axiomatic remedy for trespass on property rights is removal of the trespasser," and thus courts "should be guided by the "historical practice of protecting the right to exclude through injunctive relief given the difficulties of protecting this right solely with monetary relief." "87

Having decided to rely on such statements to the exclusion of the Apple I and Apple II decisions, the district court proceeded to emphasize the following facts that justified its ultimate finding of irreparable harm: (1) "Brocade has demonstrated that A10's infringement prevents it from practicing its patents exclusively"; (2) "Neither party has presented any evidence that Brocade licenses any of the technology in the patents to any other parties"; and (3) "Brocade also shows that it is in direct competition with A10, such that its loss of exclusivity is particularly injurious."

The district court concluded, "In a situation such as this, where Brocade has shown that it practices its patent, that A10 is its direct competitor, and that Brocade does not license its patents, Brocade has shown that it suffers the type of irreparable harm that a permanent injunction is intended to remedy." 89 On its face, this analysis entirely fails to consider or apply the nexus requirement set forth in Apple I and Apple II.

\section{B. LifeScan Draws a Line Between Inventions that Are Single Features of Complex Products and Inventions that Are a "Substantial Part" of a Product}

In LifeScan, Inc. v. Shasta Technologies, LLC, the Northern District of California entered a preliminary injunction in a manner that was highly dismissive of the nexus test as expressed by Apple II. ${ }^{90}$ The patented

85. Robert Bosch LLC v. Pylon Mfg. Corp., 659 F.3d 1142, 1149 (Fed. Cir. 2011).

86. Brocade, 2013 WL 140039, at *3 (quoting Edwards Lifesciences AG v. Core Value, Inc., 699 F.3d 1305, 1314 (Fed. Cir. 2012)) (internal quotation marks omitted).

87. Id. (quoting Presidio Components, Inc. v. Am. Technical Ceramics Corp., 702

F. 3d 1351, 1362 (Fed. Cir. 2012)) (internal quotation marks omitted).

88. Id. at $* 4$.

89. Id.

90. See 933 F. Supp. 2d 1243, 1245, 1261 (N.D. Cal. 2013), rev'd and remanded, 734 F.3d 1361 (Fed. Cir. 2013) (holding that as to the likelihood of success on the merits 
technology at issue in the case was directed to glucose monitoring systems for individuals with diabetes and in particular to improved test strips that more reliably gather blood samples to increase the accuracy of testing. ${ }^{91}$ The patentee and accused infringers were direct competitors in the testing strip market. ${ }^{92}$

In evaluating irreparable harm, the district court emphasized the fact that the parties were in direct competition and noted that the accused infringers did not seriously dispute that their sales of the accused testing strips caused price erosion and lost sales that would decrease the patentee's market share. ${ }^{93}$ The accused infringers made a primary argument based on Apple II - the patentee failed to show any causal nexus that the patented feature of the testing strips was the reason consumers were purchasing the accused products and causing the supposed harm. ${ }^{94}$

The district court took a highly dismissive view of the nexus-based argument, stating that it was "not persuaded" because

[u]nlike a smartphone, which contains a myriad of features, test strips designed for use in the OneTouch Ultra meter embody a substantial part of the patented feature and not much else. That Plaintiffs have become the market leader suggests that they possess a superior technology, the technology of the ' 105 patent. 95

Thus, the district court deemed the evidence of price erosion and lost sales sufficient to demonstrate irreparable harm. ${ }^{96}$

Doctrinally, the district court in LifeScan oversimplified the causal nexus analysis by focusing exclusively on the technological considerations. Although it may be true that an invention that is only one part of a product having a "myriad of features" is less likely to satisfy the nexus test as compared with an invention that is a "substantial part" of the product, as articulated by Apple I and Apple II, the inquiry must go further and ask more generally whether "consumers buy that product for reasons other than the patented feature." 97 Neither Apple I nor Apple II limited such

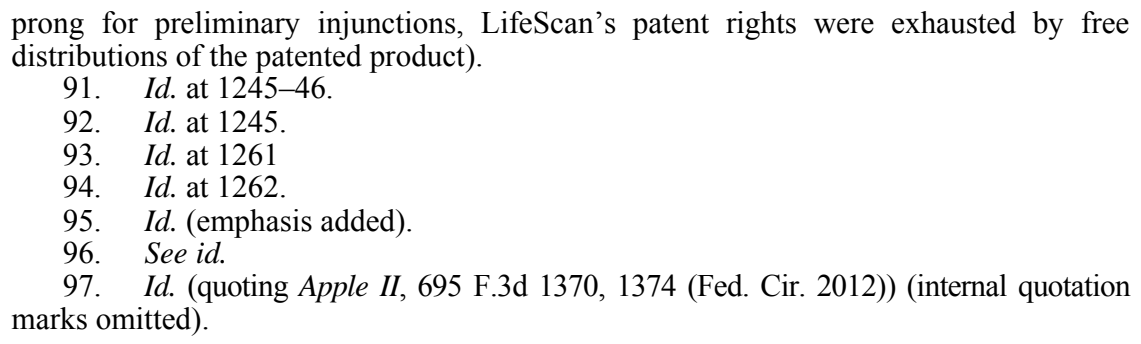


"reasons" to technological ones. At least one court has subsequently applied this more literal reading of the nexus test to include considerations of impulse purchase marketing and price in finding a lack of nexus. ${ }^{98}$ If consumers purchased the accused products because of better branding or marketing, lower pricing, or even the color or aesthetic configuration of the accused testing strips, then the nexus test may be unsatisfied even if the patented technology comprises the vast majority of how the accused testing strip works.

It may be true the patentee in LifeScan became the market leader for testing strips because of its patented technology, but that fails to acknowledge that there may be many different reasons that consumers chose to purchase the defendants' products. Consumers may or may not even care how the testing strip works as long as it works. Absent any such evidence or analysis by the district court, the preliminary injunction entered in LifeScan is not on firm ground under Apple I and Apple II.

Moreover, the nexus test does not depend on the manner in which the invention is claimed - whether the claims are drafted to cover the entire product or a component or portion thereof. Such a distinction leads to drafting gamesmanship and the potential search for the "point of novelty" or the "real invention" in a claim that is drafted to cover a whole product. The nexus test merely asks whether the harm to the patentee is caused by the infringement or something else.

\section{Douglas Dynamics Reverses a Denial of a Permanent Injunction with No Reference to Apple I or Apple II}

In Douglas Dynamics, LLC v. Buyers Products Co., the patent owner Douglas Dynamics (Douglas) sued its competitor Buyers Products (Buyers) for alleged infringement of its patented snowplow blade technology. ${ }^{99}$ Despite a finding of validity and infringement at trial, the district court denied Douglas's request for a permanent injunction based essentially on the finding that Buyers does not "directly compete" with Douglas. ${ }^{100}$ More specifically, the district court found a lack of irreparable harm because "Douglas failed to show it was losing sales or market share to Buyers."101 This conclusion was based on the facts that (1) Douglas and Buyers

98. See Am. Beverage Corp. v. Diageo N. Am., Inc., 936 F. Supp. 2d 555, 616 (W.D. $\mathrm{Pa}$. 2013) (denying patentee's request for a preliminary injunction as to its frozen beverage pouches in part because the patentee failed to show nexus and in fact argued against nexus by claiming that "frozen RTD pouches are impulse purchases made predominantly based upon price and 'appetite appeal,' not the pouch shape").

99. 717 F.3d 1336, 1338-39 (Fed. Cir. 2013).

100. Id. at 1343 .

101. Id. at 1344 . 
apparently targeted different consumers within the same snowplow market - Douglas sold higher-end products than Buyers - and (2) Douglas's market share increased by one percent a year after Buyers began selling the infringing snowplows. ${ }^{102}$

The Federal Circuit reversed with a forceful opinion, authored by Chief Judge Rader, that went on for pages about the breadth of ways that a patentee can show irreparable harm from a competitor. At the outset, Chief Judge Rader made clear that "[s]imply because a patentee manages to maintain a profit in the face of infringing competition does not automatically rebut a case for irreparable injury. Irreparable injury encompasses different types of losses that are often difficult to quantify, including lost sales and erosion in reputation and brand distinction." 103 As to the argument that Douglas and Buyers targeted different market segments, the court made an analogy to Mercedes and Ford automobiles:

Here, the district court likened Douglas's snowplow to a Mercedes Benz S550 and Buyers's snowplow to a Ford Taurus. Indeed, buyers interested in purchasing the Mercedes, when presented with both choices, would not likely switch to the Ford and vice versa. However, if the Ford made its place in the market by infringing on the intellectual property of the Mercedes and capitalized on its similarity to the better product, then the harm to the Mercedes product might go beyond a simple counting of lost sales - some of which would occur anyway if the Ford marketed itself effectively as a "Mercedes at half the price." The Mercedes would lose some of its distinctiveness and market lure because competitors could contend that they had "similar features" without noting that those features infringe Mercedes's proprietary technologies. ${ }^{104}$

As to Douglas's one percent increase in market share, the Federal Circuit viewed this fact as "immaterial" because market share can be gained for many reasons, such as reputation and investment in marketing, sales, and engineering. ${ }^{105}$ Additionally, the Federal Circuit found that Douglas's reputation as an innovator was harmed despite the absence of evidence that interested consumers confused the two companies: "Douglas's reputation as an innovator will certainly be damaged if customers found the same 'innovations' appearing in competitors' snowplows, particularly products considered less expensive and innovative."106

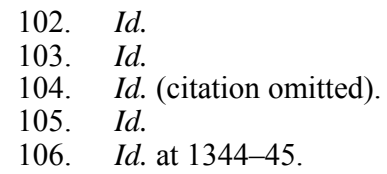


Surprisingly, neither Apple I nor Apple II is cited anywhere in the Douglas Dynamics opinion. Whether nexus was presumed or not raised by the parties, one would have expected the court at least to acknowledge the nexus requirement. Instead, Chief Judge Rader summarized his view of the case with an almost pre-eBay presumptive sentiment: "Where two companies are in competition against one another, the patentee suffers the harm - often irreparable - of being forced to compete against products that incorporate and infringe its own patented inventions." 107 Clearly, at least Chief Judge Rader feels strongly that competitive harm is an important and broadly construed factor in the injunction analysis.

Perhaps Chief Judge Rader's ignoring the Apple decisions stems from the Supreme Court's statement in eBay that rules, classifications, or "expansive principles" that might prevent injunctive relief from issuing "in a broad swath of cases" are impermissible under traditional equitable analysis. ${ }^{108}$ As he was not on either the Apple I or Apple II panels-and thus has not before spoken on the nexus test-he may feel that these cases are in direct conflict with eBay and should not be followed.

\section{APPLE III: PERMANENT INJUNCTION PROCEEDINGS}

This Part explores the application of Apple I and Apple II in the permanent injunction context after trial and how Apple's motion for a permanent injunction was denied. It also follows the course of Apple's third appeal to the Federal Circuit to obtain injunctive relief against Samsung and offers some discussion as to the potential ultimate resolution of the nexus issue.

\section{A. District Court Proceedings}

On remand, Apple prevailed at trial in proving infringement of all of the design patents discussed above, as well as Apple's utility patents directed to the "bounce back," "pinch to zoom," and "double-tap to zoom" features. ${ }^{109}$ Apple secured a \$1.05 billion jury verdict against Samsung for its infringement. ${ }^{110}$ Apple subsequently moved the district court for

107. Id. at 1345

108. eBay Inc. v. MercExchange, LLC, 547 U.S. 388, 393 (2006).

109. See Apple, Inc. v. Samsung Elecs. Co., 926 F. Supp. 2 d 1100, 1103 (N.D. Cal. 2013) (stating that "a jury found that a range of Samsung products infringe several of Apple's design and utility patents").

110. Samsung later moved for and was granted a new trial on damages because the jury failed to correctly follow the law as to when Samsung's profits could be awarded to Apple under 35 U.S.C. $\S 289$ and as to when Samsung was first on notice of Apple's patents pursuant to 35 U.S.C. $\S 287(a)$. See id. at 1112 (ordering a new trial on damages for the Galaxy Prevail product). 
a permanent injunction against Samsung's infringing products. ${ }^{11}$ The motion was ultimately denied, but in rejecting essentially all of Apple's evidence offered to show nexus, the district court provided detailed reasons for Apple's failure of proof, attempting to provide guidance as to how one might make the requisite showing.

The district court began by citing and explaining the nexus standard as set forth in Apple I and Apple II. ${ }^{112}$ It then acknowledged that the prior appeals involved preliminary injunctions but held that the framework should not change for permanent injunction proceedings. The district court reasoned, briefly and in a footnote, that "the irreparable harm requirement applies to both preliminary and permanent injunctions, and there is nothing in the Apple II opinion suggesting that its discussion of irreparable harm should be limited to the preliminary injunction context. Indeed, Courts regularly cite cases from the two contexts interchangeably." 113

In reviewing all of the evidence presented at trial and weighing all of the eBay factors, the district court denied Apple's request for a permanent injunction across the board. ${ }^{114}$ The crux of the district court's denial was Apple's alleged failure of proof of nexus-Apple did not show that it lost sales "because Samsung infringed Apple's patents." 115 Unfortunately, as explained in detail below, the district court explained why Apple's evidence was not sufficient but provided little meaningful guidance as to what evidence would have sufficed.

The district court analyzed nexus on a patent-by-patent basis, rejecting Apple's argument that the combined harm of all the infringement by each product justified an injunction. ${ }^{116}$ Additionally, the district court focused closely on the particularly claimed features covered by Apple's patents, rejecting Apple's evidence that spoke to the features at a higher level of generality. ${ }^{117}$ Although Apple presented considerable evidence that design is important to consumer choice,

111. Apple III Dist., 909 F. Supp. 2d 1147, 1149 (N.D. Cal. 2012), rev’d, 727 F.3d 1214 (Fed. Cir. 2013).

112. Id. at 1150 .

113. Id. at $1150 \mathrm{n} .2$.

114. Id. at 1163 .

115. Id. ("The fact that Apple may have lost customers and downstream sales to Samsung is not enough to justify an injunction. Apple must have lost these sales because

116. Id. at 1153 .

117. Id. at $1154-55$. 
even if design was clearly a driving factor, it would not establish the required nexus. [Because $t$ ] he design of the phones includes elements of all three design patents, as well as a whole host of unprotectable, unpatented features. Apple makes no attempt to prove that any more specific element of the iPhone's design, let alone one covered by one of Apple's design patents, actually drives consumer demand. 118

Similarly, the district court rejected Apple's consumer survey evidence and industry praise that referred to and commended certain design characteristics of Apple's and Samsung's phones. ${ }^{119}$ Although this evidence was more specific than "general 'design' allegations," it still failed to identify the patented designs and features in particular-"Apple does not have a patent on, for example, glossiness, or on black color."120 Moreover, "[o]ne consumer mentioning a feature in a survey says very little about what drives consumer demand generally, and one journalist's description of features proves nothing beyond that individual's preferences." 121

Apple's evidence as to its utility patents was similarly rejected for being too general. Apple introduced evidence that "ease of use" was important to consumers, but the fact that "[a] consumer may want a phone that is easy to use ... does not establish that a tap-to-zoom feature, for example, or any given type of gesture, is a driver of consumer demand." 122 Apple introduced a report from a consulting firm "identifying features that Apple customers like about their phones, including individual consumers' observations that you 'can enlarge pictures and move them around' and use 'gestures like a two finger pinch and flick." "123 The district court rejected this evidence as nonprobative because the

\begin{abstract}
quotations do not identify features at a level of specificity sufficient to determine whether they are actually covered by Apple's patents. Apple does not have a patent on enlarging pictures and moving them around, but rather on a specific way of enlarging pictures. Nor does Apple have a patent on the general concept of a two-finger pinch or flick. ${ }^{124}$
\end{abstract}

In any event, "evidence of what Apple customers like about their phones does not establish that any consumers bought Samsung phones because

118. Id. at 1154 ("The Federal Circuit made clear in Apple II that customer demand for a general feature of the type covered by a patent was not sufficient; Apple must instead show that consumers buy the infringing product specifically because it is equipped with the patented feature." (citing Apple II, 695 F.3d 1370, 1376 (Fed. Cir. 2012))).

119. Id. at 1155

120. Id. at 1154

121. Id.

122. Id. at 1155

123. Id

124. Id 
of these same features." 125 Similarly, the court rejected Apple's proof that Samsung intentionally copied some of Apple's patented features because it proved only "what Samsung thought would attract purchasers, not what actually attracted purchasers." 126

Finally, a survey conducted by Apple's expert asked consumers what "price premium" over the base price of a Samsung phone consumers would pay for various of Apple's patented features. ${ }^{127}$ The court also rejected this evidence because it "is not the same as evidence that consumers will buy a Samsung phone instead of an Apple phone because it contains that feature." 128 Measuring the willingness to pay for features, not products, "does not address the relationship between demand for a feature and demand for a complex product incorporating that feature and many other features." 129

Thus, the district court concluded that Apple had not satisfied the nexus requirement, and "[w]ithout a causal nexus, this Court cannot conclude that the irreparable harm supports entry of an injunction."130 The district court did, however, make additional findings relating to irreparable harm and the adequacy of money damages to compensate for the infringement. Specifically, the district court found that (1) Apple and Samsung were direct competitors that competed for first-time smartphone buyers; (2) Apple had lost market share to Samsung; and (3) the initial loss of sales to Samsung would have downstream effects, including lost future sales of future phone models and related products such as apps, laptop computers, and other accessories. ${ }^{131}$ The first two findings, according to the district court, can "support a finding of irreparable harm" and "provide some evidence that Apple may not be fully compensated by the damages

125. Id

126. Id. at 1156 .

127. Id.

128. Id. This is an inartful phrasing of the nexus requirement. The district court should have more accurately required survey "evidence that consumers will buy a Samsung phone instead of an Apple phone because it contains that feature." The district court's statement conflated the separate requirements that Apple prove (1) it lost sales to Samsung and (2) that the sales were lost because of the infringement. See Apple I, 678 F.3d 1314, 1324 (Fed. Cir. 2012) ("Sales lost to an infringing product cannot irreparably harm a patentee if consumers buy that produce for reasons other than the patented feature. If the patented feature does not drive the demand for the product, sales would be lost even if the offending feature were absent from the accused product.").

129. Apple III Dist., 909 F. Supp. 2d at 1156.

130. Id. at at 1157.

131. Id. at 1152 . 
award." 132 As noted above, the district court ultimately found that irreparable harm was lacking primarily due to Apple's failure to satisfy the nexus requirement. Regarding the adequacy of money damages, the district court discounted Apple's evidence because Apple had failed to show that its patents were "priceless" or "off limits" to licensing. ${ }^{133}$ Specifically, the district court pointed to the fact that Apple had previously offered Samsung licenses to its patents and that Apple had licensed the utility patents asserted against Samsung to Nokia, IBM, and HTC. ${ }^{134}$ According to the district court,

[t]he fact that Apple is now expressing an unwillingness to license these properties does not change the fact that Apple has, in the past, felt that money was a fair trade for the right to practice its patents, and that Apple has in the past been willing to extend license offers to Samsung. ${ }^{135}$

As to the balance of the hardships, the district court noted that Samsung had voluntarily ceased manufacture of twenty-three accused products and developed design-arounds for the remaining accused products. ${ }^{136}$ Thus, this factor was deemed "neutral.","137

Regarding whether an injunction would be in the public interest, the district court noted that the large number of products Apple sought to enjoin could result in an injunction having adverse effects on the public. ${ }^{138}$ While recognizing Apple's argument that the protection of patent rights is in the public interest, the district court also acknowledged Samsung's point that a broad injunction against many products could be "disruptive to suppliers, retailers, and customers."139 Because Samsung had voluntarily removed twenty-six products from the market and claimed to have developed design-arounds for the others, the district court viewed the alleged disruption as being overstated because it would be "limited to existing stock" and "would surely be brief." dismissed the notion that an injunction's reduction in competition would be harmful to consumers in general because "Apple and Samsung, despite being direct competitors, are not the only suppliers of mobile phones in the market, nor are Samsung's infringing phones the only phones Samsung

132. See id. at $1152,1160$.

133. Id. at 1160 .

134. Id.

135. Id.

136. Id. at 1161.

137. Id. at 1161-62.

138. See id. at 1162 .

139. Id.

140. Id. 
offers." "141 Nevertheless, the district court found that an injunction would not be in the public interest because

[i]t would not be equitable to deprive consumers of Samsung's infringing phones when, as explained above, only limited features of the phones have been found to infringe any of Apple's intellectual property. Though the phones do contain infringing features, they contain a far greater number of non-infringing features to which consumers would no longer have access if this Court were to issue an injunction. The public interest does not support removing phones from the market when the infringing components constitute such limited parts of complex, multifeatured products. ${ }^{142}$

Notably, this reasoning effectively imports a variant of the nexus requirement into the public interest analysis - a proposition that Judge Bryson rejected, as discussed above. Essentially, the district court held that when the significance of the patented features and functions within the accused product is relatively small, it would be against the public interest to enjoin the entire product.

In ultimately denying the permanent injunction, the district court again focused on the irreparable harm prong and summarized its reasoning as follows:

Weighing all of the factors, the Court concludes that the principles of equity do not support the issuance of an injunction here. First and most importantly, Apple has not been able to link the harms it has suffered to Samsung's infringement of any of Apple's six utility and design patents that the jury found infringed by Samsung products in this case. The fact that Apple may have lost customers and downstream sales to Samsung is not enough to justify an injunction. Apple must have lost these sales because Samsung infringed Apple's patents. Apple has simply not been able to make this showing. Though this is a case where the "plaintiff practices its invention and is a direct market competitor," [Edwards Lifesciences AG v. CoreValve, Inc., 699 F.3d 1305, 1315 (Fed. Cir. 2012)], it is not a case where the patented inventions are central to the infringing product. Without the required causal nexus, the parties' status as direct competitors simply does not justify an injunction. 143

Finally, the district court deemed its decision justifiable and in accordance with Justice Kennedy's observation in eBay that "[w] hen the patented invention is but a small component of the product ... and the threat of an injunction is employed simply for undue leverage in negotiations, legal damages may well be sufficient to compensate for the infringement

141. Id.

142. Id. at 1163 .

143. Id. (emphasis added). 
and an injunction may not serve the public interest." ${ }^{\text {144 }}$ As to Apple in particular, the district court reasoned that "[t]hough Apple does have some interest in retaining certain features as exclusive to Apple, it does not follow that entire products must be forever banned from the market because they incorporate, among their myriad features, a few narrow protected functions." 145

\section{B. Apple's Position on Appeal to the Federal Circuit}

On appeal, Apple lodged three primary attacks on the district court's decision. First, Apple contested whether the nexus requirement was appropriate at all in a permanent injunction context. ${ }^{146}$ Second, Apple argued that the district court placed undue emphasis on the nexus requirement to the exclusion of the remaining eBay factors and considerations, which together weigh heavily in favor of a permanent injunction. ${ }^{147}$ Third, Apple contended that even if the nexus standard applied, it was improper for the district court to strictly consider the evidence on a patent-by-patent basis and that in any event, Apple's evidence was sufficient to warrant a permanent injunction. ${ }^{148}$ Finally, Apple suggested that even if the nexus test was applied correctly and Apple failed to satisfy the test, injunctive relief should not be entirely denied but should be appropriately tailored. ${ }^{149}$

\section{The Propriety of a Nexus Requirement for Permanent Injunctions}

Apple's appeal brief emphasized that the district court cited Apple's alleged failure to prove nexus as the "first and most important" reason for denying the permanent injunction. ${ }^{150}$ Yet, Apple correctly noted that a nexus requirement had never been previously imposed in a permanent injunction context and that neither Apple I nor Apple II purported to extend beyond the preliminary injunction context before the Federal Circuit in those cases. ${ }^{151}$ Although Apple previously sought the "extraordinary" relief of a preliminary injunction that alters the status quo before any finding of wrongful conduct by Samsung had occurred, now

144. Id. (quoting eBay Inc. v. MercExchange, LLC, 547 U.S. 388, 396-97 (2006)

(Kennedy, J., concurring) (internal quotation marks omitted)).

145. Id. at 1164.

146. Brief for Plaintiff-Appellant Apple Inc. at 2-3, 27-29, Apple III, 735 F.3d

1352 (Fed. Cir. 2013) (No. 13-1129) [hereinafter, Apple III Appeal Brief].

147. Id. at 50 .

148. Id.

149. Id. at $58-59$.

150. Id. at 47 (internal quotation marks omitted).

151. See id. 
that Samsung is an adjudged infringer, Apple argued that the "right to exclude" afforded to it with its patents was triggered and should be meaningful. ${ }^{152}$ The nexus requirement was alleged to be simply too onerous to satisfy in cases where "a single patent does not cover an entire product, but only an innovative design or feature within a larger product"-to deny injunctive relief for virtually all such patents effectively eviscerates the patents' exclusionary rights. ${ }^{153}$

According to Apple, particularly where the adjudged infringer is a direct competitor of the patentee, as with Apple and Samsung, courts have frequently granted permanent injunctive relief regardless of any causal nexus. ${ }^{154}$ These results are appropriate in Apple's view because, as was noted by both Justice Kennedy and Chief Justice Roberts in eBay, typical patent litigation between competitors that results in a competitor being found to infringe would more often than not result in a weighing of the four equitable factors in favor of entering a permanent injunction. ${ }^{155}$

Apple reminded the Federal Circuit that eBay not only set forth the exclusive four-factor test for permanent injunctive relief, which makes no reference to "nexus," but also cautioned that "a major departure from the long tradition of equity practice should not be lightly implied."156 The nexus requirement is undoubtedly a substantial and rigid requirement as applied by the district court. Suggesting that the nexus requirement is indeed a major departure from traditional injunction analysis, Apple cited recent post-eBay Federal Circuit decisions supporting the entry of permanent injunctions without any mention of a causal nexus requirement. ${ }^{157}$

152. Id. at 51, 52 (emphasis omitted) (quoting Winter v. Natural Res. Def. Council, Inc., 555 U.S. 7, 22, 24 (2008)) (internal quotation marks omitted).

153. Id. at 54.

154. Id. at 53-54 (citing Whitserve, LLC v. Computer Packages, Inc., 694 F.3d 10, 35 (Fed. Cir. 2012); Robert Bosch LLC v. Pylon Mfg. Corp., 659 F.3d 1142, 1150-51 (Fed. Cir. 2011); i4i Ltd. P'ship v. Microsoft Corp., 598 F.3d 831, 861 (Fed. Cir. 2010)).

155. Id. at 48-49 (quoting eBay Inc. v. MercExchange, L.L.C., 547 U.S. 388, 395 (2006) (Roberts, C.J., concurring) (explaining that "“a page of history is worth a volume of logic' in reference to the historical practice of 'granting injunctive relief upon a finding of infringement in the vast majority of patent cases"”); id. at 396 (Kennedy, J., concurring) ("To the extent earlier cases establish a pattern of granting an injunction against patent infringers almost as a matter of course, this pattern simply illustrates the result of the four-factor test in the contexts then prevalent." (internal quotation marks omitted))).

156. Id. at 48 (quoting eBay, 547 U.S. at 391) (internal quotation marks omitted).

157. Id. at 49-50 (citing Robert Bosch LLC, 659 F.3d at 1152-55; Broadcom Corp. v. Qualcomm Inc., 543 F.3d 683, 701-03 (Fed. Cir. 2008); Acumed LLC v. Stryker Corp., 551 F.3d 1323, 1329 (Fed. Cir. 2008)). 
Yet, the district court denied Apple's request for a permanent injunction "[f]irst and most importantly" because of the alleged lack of nexus and appeared to weigh the irreparable harm factor-actually one consideration within the irreparable harm analysis - far more heavily than the other factors. ${ }^{158}$ The district court's analysis appears inconsistent with its statement that it had "[w]eigh[ed] all the factors" to arrive at its conclusion, particularly because the district court expressly stated that "[w]ithout the required causal nexus, the parties' status as direct competitors simply does not justify an injunction." 159 Such an apparently rigid rule conflicts with eBay's pronouncement that "categorical" denial of injunctive relief is the kind of "analysis [that] cannot be squared with the principles of equity adopted by Congress." 160

\section{Analysis of the Four eBay Factors}

Looking at all of the eBay factors and the relevant factual considerations, Apple contended that it was an abuse of discretion not to enter a permanent injunction against Samsung given the factual findings made by the district court. As noted above, the district court found that Apple and Samsung were direct competitors, that Apple had lost market share to Samsung, and that this initial loss of sales to Samsung would have downstream effects on sales and customer retention but found that the lack of nexus precluded a finding of irreparable harm.

Apple sharply criticized the district court's reliance on Apple's supposed willingness to license its patents as proof of the adequacy of money damages. Apple pointed out that the licenses to Nokia, IBM, and HTC were limited to utility patents and included none of Apple's design patents. ${ }^{161}$ Moreover, the district court failed to address the particular circumstances of the licenses, in particular the fact that the license to IBM was executed five years before the launch of the iPhone in 2007 and was "part of a broad cross-license with a company that does not sell smartphones." 162 The Nokia and HTC agreements were litigation settlements of limited value in assessing the business reasons for the licenses but in any event were limited in scope and directed to preventing "clones" of Apple products. ${ }^{163}$ According to Apple, these licenses are consistent with Apple's strong desire not to license its unique user

158. Apple III Dist., 909 F. Supp. 2d 1147, 1163 (N.D. Cal. 2012), rev'd, 727 F.3d 1214 (Fed. Cir. 2013).

159. Id.

160. eBay, 547 U.S. at 393-94.

161. Apple III Appeal Brief, supra note 146, at 39.

162. Id. at $39-40$.

163. Id. at $40-41$. 
experience to direct competitors and to maintain such features and functions exclusively. ${ }^{164}$ Furthermore, although the district court noted that Apple had previously licensed "some [of its] patents" to Samsung, Apple contended that no such offer was ever made for the patents-in-suit because Apple viewed the patents-in-suit as "untouchables." 165

As to the balance of the hardships, Apple argued that Samsung's voluntary removal of accused products and supposed low-cost designarounds did not obviate the need for an injunction. ${ }^{166}$ Apple alleged,

Because Samsung frequently brings new products to market, an injunction is essential to providing Apple the swift relief needed to combat any future infringement by Samsung through products not more than colorably different from those already found to infringe. Apple should not have to bear the risk that Samsung's supposed design-arounds are insufficient or that Samsung will not again resume its infringement. ${ }^{167}$

Additionally, if Samsung indeed stopped selling twenty-six products and could easily implement design-arounds for the remaining products, then the hardship to Samsung would be minimal. ${ }^{168}$ Thus, Apple contends that the balance of the hardships is not neutral but favors the entry of an injunction.

Regarding the public interest, Apple emphasized the importance of protecting patent rights, noting that " $[\mathrm{t}] \mathrm{he}$ public interest in patent enforcement is particularly strong where, as here, an injunction will not implicate public safety issues, but will only prevent Samsung from unfairly competing with Apple by selling products that use Apple's patented designs and features." 169 The recognized availability of other smartphones in the marketplace undercut the notion of any substantial detriment to the public if Samsung were to be enjoined. ${ }^{170}$ Apple also criticized the district court for expressing reluctance to issue a "broad injunction" covering Samsung's more than twenty-six infringing products: "Samsung cannot avoid an injunction simply because its infringement involved many products. To

164. Id. at 41 .

165. Id. at 38 (internal quotation marks omitted).

166. Id. at $41-42$.

167. Id. at 42 (citation omitted).

168. See id.

169. Id. at 44 .

170. Id. at 44-45. 
the contrary, the public's interest would be served by ending such broadranging infringement." 171

\section{Application of the Nexus Requirement}

Even if the nexus requirement were proper in the permanent injunction context, Apple argued on appeal that the district court's insistence on applying the test on a patent-by-patent basis was improper and not required by Apple I or Apple II. ${ }^{172}$ Requiring each infringing feature to independently drive demand for the accused products "would be difficultif not impossible - to show for products embodying multiple patented features, where it is unlikely that a patentee could offer proof that each patented feature independently drove demand."

Apple also took issue with the district court's weighing of the evidence it offered to prove nexus under the standard as applied by the district court. Apple presented considerable and undisputed evidence at trial that consumers find product design and user interface to be important influences in their decisionmaking when buying smartphones and tablets. ${ }^{174}$ The patented features, both design and utility, were argued to be "such large components of the overall design and ease-of-use of Samsung's infringing smartphones that Apple's undisputed evidence of the importance of those features to consumers should have been more than sufficient to demonstrate a causal nexus between Samsung's infringement and the irreparable harm Apple has suffered." 175 Apple vehemently disputed the district court's dismissal of its various third-party assessments and surveys regarding the importance and value of the patented features. ${ }^{176}$ This third-party praise and survey evidence touted the same "beautiful" and "cool" design features in both Apple's and Samsung's products, making specific reference to the general "sleek" and "rounded" overall design, as well as specific portions covered by the design patents - the "shiny black face" that is "rimmed by mirror-finish stainless steel." 177

As to the utility patents, third-party praise and consumer survey evidence likewise showed that Apple's "easy and intuitive" user interface "is the major driver of [consumer] interest in touch" screens because it makes the user interface "real magic" and "wicked cool" without being difficult

171. Id. at 45 .

172. Id. at $48-50$.

173. Id. at 50 .

174. See id. at 61.

175. Id. at 62 .

176. See supra Part VI.A.

177. Apple III Appeal Brief, supra note 146, at 62-63 (internal quotation marks omitted). 
to use. ${ }^{178}$ More specifically, third-party praise and surveys touted the individually patented functions, noting that the "two finger pinch" and "bounce" functions make using the products "fun" and that the "double tap" zooming is "the most preferred method" for such functionality. ${ }^{179}$

Overall, Apple rejected the district court's insistence that this thirdparty praise and survey evidence were "simply too general" and failed to clearly relate to the patented features. ${ }^{180}$

\section{Appropriately Tailoring Injunctions when the Nexus Requirement Is Not Satisfied}

Apple suggested to the Federal Circuit that even if the nexus requirement was applicable, correctly applied, and unsatisfied by Apple, Apple still should not be denied injunctive relief entirely. Rather, Apple proposed a more "flexible" approach, whereby an injunction could be issued but the district court could use its equitable discretion to delay enforcement to allow the defendant time to implement a design-around. ${ }^{181}$ Such "sunset provision[s]" have been approved by the Federal Circuit in the past in situations where it would have been "inequitable to require immediate compliance" with an injunction. ${ }^{182}$

Importantly, in support of its flexible injunction approach, Apple expressly relied on the Federal Circuit's entire market value rule precedent to draw a helpful analogy. ${ }^{183}$ Apple first made clear that the nexus requirement is substantively identical to the entire market value rule:

This flexible approach to permanent injunctions is entirely consistent with the closely-related relationship between the entire market value rule and reasonable royalty damages. To recover a reasonable royalty based on the entire value of an accused product, the patentee must show — as with the causal nexus requirementthat the patent either claims the entire product or else a smaller feature that drives demand for the entire product. See Garretson v. Clark, 111 U.S. 120, 121 (1884); Uniloc USA, Inc. v. Microsoft Corp., 632 F.3d 1292, 1318 (Fed. Cir. 2011); see also LaserDynamics, 694 F.3d at 67 ("[T] he entire market value rule allows damages based on the value of an entire apparatus containing several

178. Id. at 64-65 (internal quotation marks omitted).

179. Id. (internal quotation marks omitted).

180. Id. at 66 (internal quotation marks omitted).

181. Id. at $57-59$.

182. Id. at 57 (citing Broadcom Corp. v. Qualcomm Inc., 543 F.3d 683, 704 (Fed. Cir. 2008); Verizon Servs. Corp. v. Vonage Holdings Corp., 503 F.3d 1295, 1311 n.12 (Fed. Cir. 2007)).

183. See id. at 58. 
features, when the patented feature constitutes the basis for customer demand." (emphasis added) (quoting Lucent Techs., Inc. v. Gateway, Inc., 580 F.3d 1301, 1336 (Fed. Cir. 2009))). 184

Apple went on to point out that in the damages context, failure to satisfy the entire market value rule does not deprive the patentee of a remedyit merely limits the remedy that may be obtained:

But the failure to prove that the patented feature "drives demand" does not mean that the patentee gets no damages at all; it simply means that the patentee must apportion part of the entire product's value to the patented feature, so that the patentee does not recover more than the value of what has been invented. Indeed, a patentee still can obtain a reasonable royalty without satisfying the entire market value rule, which after all "is a narrow exception" to the general damages rule. LaserDynamics, 694 F.3d at 67.185

Because neither the Federal Circuit nor the Supreme Court has ever recognized the nexus requirement as a similar kind of "narrow exception" when $e$ Bay's four-factor test otherwise renders a permanent injunction appropriate, Apple proffered that the "solution is to allow courts to exercise their considerable discretion to sculpt injunctions so as to permit defendants to implement design-arounds, which would - like the entire market value rule-prevent the patentee from reaping a windfall without denying relief entirely."

\section{Potential Ways To Resolve the Nexus Issue}

As explained above, Apple presented the Federal Circuit with several avenues to decide the case. As noted below, however, a Federal Circuit panel has decided the Apple III appeal but has done so in a manner inconsistent with the prior Apple I and Apple II decisions, leaving the Apple III decision of questionable precedential value and the nexus issue ripe for en banc consideration. Thus, all of the arguments made by Apple and those discussed below remain very much in play for future appeals that challenge the nexus requirement. Given the importance of the issue to nearly every patent litigation matter, sooner or later an en banc petition on the nexus issue will garner sufficient attention at the Federal Circuit to be granted and will attract a substantial amount of amicus support on both sides.

If the Federal Circuit ultimately agrees with Apple that the nexus requirement is inappropriate to import into the permanent injunction context, then Apple will likely ultimately secure a permanent injunction

184. Id.

185. Id. at $58-59$.

186. Id. at 59. 
because the district court placed great weight on Apple's failure to show nexus and because the remaining considerations under eBay generally favor the entry of an injunction under precedent such as Bosch.

In order to hold that no nexus requirement applies for permanent injunctions, presumably the Federal Circuit would have to take an approach similar to that in Brocade, discussed above. That is, the Federal Circuit would likely pay lip service to Apple I and Apple II but highlight the differences between preliminary and permanent injunctions and rely on cases such as Bosch to emphasize the importance that a patent's exclusionary right be meaningful. As a matter of doctrinal clarity, it would not be ideal to have such a distinction made without a well-defined difference in how the irreparable harm factor is analyzed for preliminary and permanent injunctions.

The nexus requirement, as applied in the preliminary injunction context, would arguably not need to be revisited in Apple III unless the Federal Circuit decided to hear the case en banc and reconsider-and potentially overrule-Apple I and Apple II. Apple specifically requested in its appeal brief that the appeal be heard en banc to the extent the Federal Circuit believes that Apple I and Apple II prevent the court from granting Apple the relief it seeks. ${ }^{187}$ Again, from a doctrinal clarity standpoint, to the extent the Federal Circuit sees fit to modify or abrogate the nexus requirement, treating all the Apple cases together would be the most sensible.

If, however, the nexus requirement is deemed applicable for only permanent injunctions, or is deemed applicable in a modified form for permanent injunctions, then the Federal Circuit will have several important questions to resolve. Each will now be taken in turn.

\section{When and How Does the Nexus Requirement Apply to Permanent Injunctions?}

First and foremost, the Federal Circuit will have to explain why it never raised the nexus requirement in any of its permanent injunction decisions post-eBay or even post-Apple I. Although the Federal Circuit has been clear that the irreparable harm analysis does not significantly differ between preliminary and permanent injunction contexts, ${ }^{188}$ it would need to address that its recent decisions failed to discuss or impose any

187. Id. at $66-67$.

188. See Robert Bosch LLC v. Pylon Mfg. Corp., 659 F.3d 1142, 1148 n.3 (Fed. Cir. 2011) (quoting Amoco Prod. Co. v. Vill. Of Gambell, 480 U.S. 531, 546 n.12 (1987)). 
nexus requirement. For example, Presidio Components, Inc. v. American Technical Ceramics Corp. ${ }^{189}$ and Edwards Lifesciences AG v. CoreValve, Inc., ${ }^{190}$ both of which were decided after Apple I and Apple II, involved patented heart stents and capacitors where the accused products were heart stents and capacitors, not larger products incorporating heart stents and capacitors. ${ }^{191}$ However, no analysis was done to determine whether the patented feature - as opposed to other features, marketing efforts, pricing, et cetera-drove the demand for the infringing products.

If the nexus requirement is indeed a legal requirement for permanent injunctions, one would think that the Federal Circuit would have remanded those cases in light of Apple I and Apple II, even if the parties themselves did not raise the nexus issue. To say that the nexus issue was simply not implicated by the facts in all post-eBay cases until Apple I does not appear accurate. In LifeScan, discussed above in Part V.B, the court drew a line between an invention that is only one part of a product having a "myriad of features" and an invention that is a "substantial part" of the product, as a way to effectively avoid application of the nexus test. Even there, where the nexus test was expressly discussed, the line-drawing exercise failed to capture the full scope of the nexus inquiry, which encompasses nontechnical reasons that accused products might be purchased as well as technical reasons. Thus, the nexus requirement does appear to be applicable even in cases where the patented features include the majority or the entirety of the accused product, and the Federal Circuit will need to squarely address this point to bring clarity to the nexus doctrine and avoid more decisions such as LifeScan.

Along these lines, in i4i Limited Partnership v. Microsoft Corp., a case decided after eBay but before Apple I, the Federal Circuit affirmed the entry of a permanent injunction against Microsoft's ubiquitous, multifaceted, and powerful Word word processing and editing program. ${ }^{192}$ The patent that Microsoft was enjoined from infringing covers a modest "custom XML" editor feature-an "add-on" functionality to Word that enables Word to work with documents containing custom XML. ${ }^{193}$ Custom XML is only one of many markup languages that exist, and it was estimated that only $1.9 \%$ of Word users even utilized the patented feature. ${ }^{194}$ Such facts strongly suggested that users of Word did not

189. 702 F.3d 1351 (Fed. Cir. 2012).

190. 699 F.3d 1305 (Fed. Cir. 2012).

191. See Presidio Components, 702 F.3d at 1354; Edwards Lifesciences, 699 F.3d at 1307.

192. 598 F.3d 831, 840-41, 864 (Fed. Cir. 2010).

193. Id. at 839 .

194. Id. at 855 . 
purchase the product because of its custom XML editor, but no discussion of a causal nexus requirement occurred during the court's irreparable harm analysis. ${ }^{195}$ Nevertheless, the court deemed a permanent injunction appropriate because i4i and Microsoft were direct competitors in the custom XML market, i4i lost market share to Microsoft, and Microsoft's infringement "rendered i4i's product obsolete." 196 In Apple I, the Federal Circuit explained that

[t]he narrow injunction upheld by this court [in i4i] served only to protect the patented product from obsolescence by its inclusion within Word. Here, in contrast, the district court found that the alleged acts of infringement do not threaten to have any such dramatic effects on the market generally or on Apple's share of that market. 197

To the extent the nexus requirement applied, but was not stated, in i4i, this market eradication rationale would appear to constitute an exception to the nexus requirement that the Federal Circuit would need to clarify en banc.

\section{Is the Nexus Issue Better Considered Under eBay Factors Three and Four?}

Both the district court and the Federal Circuit have analyzed the causal nexus between infringement and lost sales under the eBay factor of irreparable harm. There is logic behind analyzing nexus in this lightone cannot say a patentee's lost sales harm the patentee in a way that implicates the patentee's patent rights unless there is some relationship between the infringing sales and the patented feature. However, to require proof that the infringing feature is essentially the reason that the infringing product was purchased may go too far. As Apple argued in Apple I, maybe it should be enough to show that the patented feature exists in the infringing product and that the sale of the infringing product was a lost sale to the patentee. That situation certainly presents a harm to the patentee that directly treads on the patentee's exclusive right and can be viewed as irreparable harm, especially when coupled with additional factors such as a direct competitive relationship and downstream lost sales.

195. See id. at 861-62.

196. Id.

197. Apple I, 678 F.3d 1314, 1324 (Fed. Cir. 2012) (citation omitted). 
Perhaps the same kind of analysis concerning the relative importance of the patented feature can be more appropriately and more equitably considered elsewhere in the injunction analysis. Although Judge Bryson rejected the contention that causal nexus should be considered in the context of eBay factors three and four, in Apple I, the U.S. District Court for the Northern District of California in Brocade disagreed, stating, "Whatever its ultimate merit where the particular irreparable harm claimed is a loss of sales, that strict standard appears to move into the irreparable harm analysis a consideration better suited for the equitable factors of balance of hardships and public interest."198

In denying Apple's motion for a permanent injunction, the district court made statements in connection with factors three-balance of the hardships - and four - public interest - that are closely related to the nexus inquiry purportedly relevant only to irreparable harm. Specifically, the district court noted that Samsung was able to design around Apple's patents without considerable burden or expense, rendering the balance of the hardships at worst a neutral factor. ${ }^{199}$ Presumably, it was the perception that Apple's patents standing alone encompassed relatively small or unimportant features of Samsung's products that enabled Samsung to implement designarounds without incurring substantial hardship. Indeed, if Apple's patented designs and inventions were central to the commercial success of Samsung's products, Samsung would not voluntarily design around the patents or would find it to be an immense burden and cost to do so. The costs to Samsung in implementing a design-around of highly important features would extend beyond the cost of retooling and redesigning its products and may well include lost sales due to Samsung's inability to provide the desirable features for its customers. On the other hand, as the district court observed, "one who elects to build a business on a product found to infringe cannot be heard to complain if an injunction against a continuing infringement destroys the business so elected."200 The more important the patented features in the scheme of the infringing product, the more unfair it becomes to deem the infringer's hardship as cognizable. These competing considerations allow for equitable weighing to take place in a way that the nexus requirement for irreparable harm does not.

Similarly, the district court found that an injunction would not be in the public interest essentially because "[t]he public interest does not support

198. Brocade Commc'ns Sys. v. A10 Networks, Inc., No. C 10-3428 PSG, 2013 WL 140039, at *3 (N.D. Cal. Jan. 10, 2013).

199. See Apple III Dist., 909 F. Supp. 2d 1147, 1161-62 (N.D. Cal. 2012), rev'd, 727 F.3d 1214 (Fed. Cir. 2013).

200. Id. at 1161 (quoting Telebrands Direct Response Corp. v. Ovation Commc'ns, Inc., 802 F. Supp. 1169, 1179 (D.N.J. 1992) (internal quotation marks omitted). 
removing phones from the market when the infringing components constitute such limited parts of complex, multi-featured products."201 The emphasis on the relatively small role the patented designs and inventions were deemed to play in the infringing products once again echoes the lack of nexus finding. Conversely, if the patented features were driving the demand for the Samsung products, then the harm to the public from an injunction would arguably be greater because it would deprive consumers of a substantial source of the smartphone features that they find especially important and useful. On the other hand, the well-established importance of protecting patent rights in such a classic unfair competition situation - particularly where the patented features do not implicate public safety or health concerns - may well trump the inconvenience to the public. Again, these competing considerations would allow for equitable weighing to take place in a way that the nexus requirement for irreparable harm does not.

Overall, if the facts of the case would satisfy the nexus requirement in its current form for proving irreparable harm, then it is more likely that the balance of the hardships, the public interest factors, or both would favor the entry of an injunction. If the facts of the case would suggest a lack of nexus, an injunction would be less likely upon consideration of the balance of the hardships and the public interest. The district court's permanent injunction decision supports this view and gives credence to the doubt expressed in Brocade about the propriety of evaluating the nexus considerations exclusively in the irreparable harm analysis.

If the Federal Circuit were to modify and reallocate some of the nexus considerations into the balance of the hardships and public interest factors, the inflexible and onerous nature of the nexus test might be relaxed to a point that allows for more robust consideration of fairness and equity when presented with patents that cover only portions of infringing products.

201. Id. at 1163 . 


\section{Must the Nexus Requirement Be Analyzed on a Patent-by-Patent Basis?}

The district court explicitly and rigidly analyzed the nexus requirement on a patent-by-patent basis, requiring that a patented feature or function individually drive demand for the accused Samsung product in order for the nexus requirement to be satisfied. ${ }^{202}$ However, when taken together, Apple's patented features and functions found within the accused products undoubtedly take on a greater role influencing purchasing decisions.

When courts find that accused products infringe multiple patentspatents that together reflect many core design features and functionalities of the accused products - perhaps it makes sense to consider the effect of those patented features and functions in the aggregate. Effectively, multiple infringing features present in the same device may drive demand whereas one feature alone might not. In that case, it seems equitable to find the nexus standard satisfied as to the particular product.

If nexus must be found as to a single patented feature or function, Apple's patents, which are not exceedingly narrow in scope, will likely continue to be insufficient to obtain any injunctive relief. As discussed above, Apple I and Apple II, like LaserDynamics and Lucent, are all probably correct that the individual patented features at issue in those cases are not alone the reasons that consumers purchased the products. If the nexus requirement remains as is, it is clear that Apple and similarly situated patentees will have, at best, an uphill battle to obtain injunctions in the future, particularly preliminary injunctions. Apportioning the relative value and importance of each component's contribution to a complete product is not a straightforward or objective task, but an accused infringer such as Samsung can fairly easily identify reasons that consumers buy their products other than a patented design or any other hardware or software features standing alone. The presence of Samsung's goodwill and brand recognition, as well as its products' many software and hardware functionalities not covered by Apple's patents, especially in the aggregate, can dispel the notion that a single patented feature is the reason purchasers selected a Samsung product instead of an Apple product.

Although the Federal Circuit might have been comfortable with the strict nexus requirement in the preliminary injunction context, once a defendant is an adjudged infringer, the legal relationship of the parties is very different and the Federal Circuit may be reluctant to completely deny Apple injunctive relief as to its infringing direct competitor. One way to achieve some equitable balance would be to allow consideration of all infringed patents in the aggregate and their effect on consumer

202. See id. at 1153. 
purchasing decisions. If multiple patents are infringed and those patented features together comprise the reasons that drive customers to purchase the infringing products, the harm from the lost sales is readily traceable to Apple's patents and injunctive relief should at least be possible.

\section{What Evidence Suffices To Show Nexus?}

As discussed above in Part VI.A, the district court provided detailed discussion of Apple's evidence offered to prove nexus and why it was deemed insufficient but gave virtually no indication as to what evidence would have sufficed. The district court's dismissal of Apple's evidence largely boils down to the evidence allegedly being "simply too general" and not expressly tied to the specific patents at issue. ${ }^{203}$ Apple made a compelling case on appeal that the district court was unfairly dismissive of Apple's third-party praise and survey evidence tending to show that the patented features drove demand. ${ }^{204}$ For example, Apple expressed frustration in the face of the district court's insistence that Apple's survey evidence, which showed that ease of use was a very important consideration for purchasers, was entirely nonprobative because it failed to clearly tie the survey evidence "to each patented feature." 205 Specifically, Apple represented to the Federal Circuit that "no consumer survey can readily ask consumers about particular patent claims or claim limitations at that level of specificity." 206

Even if this representation is a bit overblown, when taken in light of all the evidence, ${ }^{207}$ Apple made a showing of nexus that was at least entitled to more weight than it was given by the district court, which effectively gave Apple's evidence zero weight. ${ }^{208}$

203. See id. at 1155.

204. See supra Part VI.B.3.

205. Apple III Appeal Brief, supra note 146, at 54-55.

206. Id.

207. The evidence included third-party praise and surveys that referred to the patented features both generally and specifically. See supra Part VI.B.3 (discussing evidence that referenced the "easy and intuitive" user interface, including the "two finger pinch," "bounce," and "double tap" features, as well as the "beautiful," "sleek," and "rounded" design, including the "shiny black face" that is "rimmed by mirror-finish stainless steel").

208. See, e.g., Apple III Dist., 909 F. Supp. 2d at 1154 (“Apple makes no attempt to prove that any more specific element of the iPhone's design, let alone one covered by one of Apple's design patents, actually drives consumer demand."); id. ("[E]ven if these quotations did specifically reference the precise designs covered by Apple's patents, they 
Given the manner in which the district court dismissed Apple's evidence outright, it appears that Apple could not have proven nexus without survey evidence that poses a consumer with the question "Why did you buy this Samsung product?" and the consumer's answer specifically identifies a patented design feature or functionality as the sole or primary reason. Importantly, the consumer's answer cannot be phrased in generalities - it must identify a feature in a manner that specifically falls within the scope of one of Apple's patents. For example, with respect to Apple's U.S. Patent No. D593,087, shown below, it would not be enough to answer, "I liked the design."; one would have to answer to the effect that "I liked the design having a flat front and rounded corners with a narrow oblong opening for the speaker and a quarter-rounded bezel surrounding the screen, which is rectangular and extends width-wise to the bezel and length-wise toward the speaker opening but stopping short of the bezel."

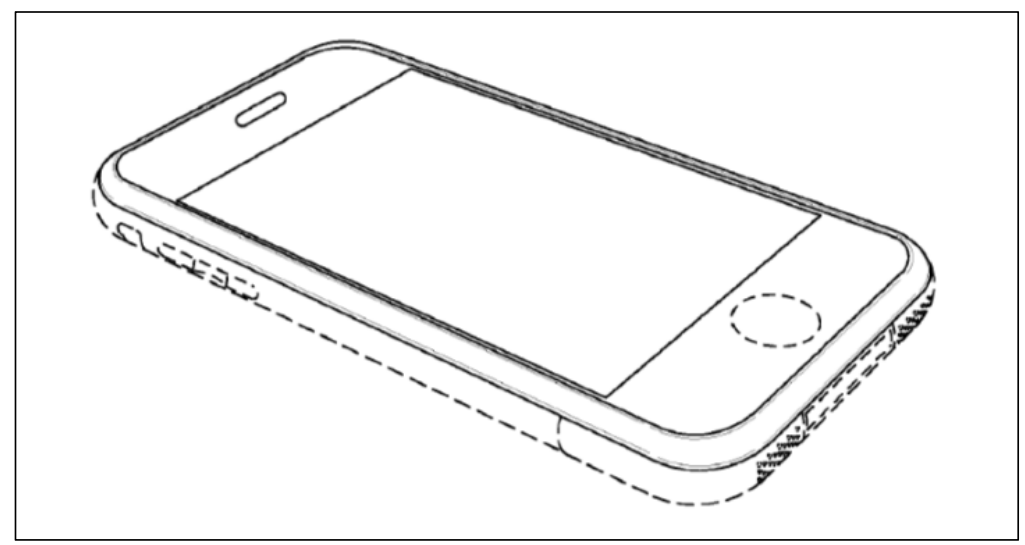

APPLE’S U.S. PATENT No. D593,087, FIG. 41

Similarly, it appears that as to Apple's U.S. Patent No. 7,884,915, it would not be sufficient for a customer to say, "I like the intuitive and easy-to-use design," or even, "I like that I can pinch to zoom in on images," but would have to track the claim language more closely:

do not begin to prove that those particular features drive consumer demand in any more than an anecdotal way."). 
A machine implemented method for scrolling on a touch-sensitive display of a device comprising:

- receiving a user input, the user input is one or more input points applied to the touch-sensitive display that is integrated with the device;

- creating an event object in response to the user input;

- determining whether the event object invokes a scroll or gesture operation by distinguishing between a single input point applied to the touch-sensitive display that is interpreted as the scroll operation and two or more input points applied to the touch-sensitive display that are interpreted as the gesture operation;

- issuing at least one scroll or gesture call based on invoking the scroll or gesture operation;

- responding to at least one scroll call, if issued, by scrolling a window having a view associated with the event object based on an amount of a scroll with the scroll stopped at a predetermined position in relation to the user input;

- and responding to at least one gesture call, if issued, by scaling the view associated with the event object based on receiving the two or more input points in the form of the user input. 209

Of course, no consumer would give such highly technical and detailed answers to the simple question of why the consumer purchased a product, which begs the question of how one can ever prove nexus.

Although surveys can be structured in many different ways, a less open-ended form of questioning is likely to have methodological problems that could diminish the weight or even preclude the admission of the survey. For example, in the trademark litigation context where survey evidence is commonplace, surveys can easily be discounted for poor phrasing of questions or for asking leading questions. ${ }^{210}$ To ask Samsung purchasers whether the patented features are what motivated them to buy their phones or tablets would inherently require the questions to attempt to accurately capture the scope of the claimed designs and invention. Given the various nuances of claim interpretation and infringement analysis, constructing such questions to be clear and understandable to the survey subjects while still being accurate is like navigating a densely packed mine field where any misstep can be fatal. For example, to explain how a patent is to be interpreted and understood before asking whether the

209. U.S. Patent No. 7,884,915 col. 9 I. 52-col. 10 I. 28 (filed Mar. 16, 2007).

210. See generally 6 J. Thomas McCarthy, McCarthy on Trademarks and Unfair Competition $\S \S 32.171-173$ (4th ed. 2014). 
patented feature is the reason that the consumer purchased the product could easily be criticized as the surveyor "lead[ing] the interviewee "along the garden path' to the desired response."211

Under Apple I and Apple II, it is easy to understand what does not satisfy the nexus test but almost entirely obscured is how one might satisfy the test as a practical matter. The sole instance where the Federal Circuit found nexus to be proven was for the ' $889^{212}$ (iPad) patent, where it emphasized the importance of design to tablet purchasers and the fact that only two manufacturers, Apple and Samsung, "together controlled a substantial share of the market." 213 Short of those circumstances, which may apply only when brand new classes of products, not new models of existing products, are emerging, no patented feature has satisfied the nexus test on appeal.

The district court's dismissal of the evidence in the permanent injunction proceedings sheds no additional light on how to meet the nexus requirement. To the extent that the Federal Circuit maintains the nexus requirement in its current form, Apple's arguments on appeal make a good case that the current standard is essentially impossible to satisfy for patents directed to components of larger products. If this was not the Federal Circuit's intention when endorsing the nexus requirement, then further guidance as to how the test can be satisfied would be immensely helpful.

\section{Can an Appropriately Tailored Injunction with a "Sunset Provision" Strike the Correct Equitable Balance?}

As noted above in Part VI.B.4, Apple suggested that even if the nexus requirement applies exactly as in Apple I and Apple II to permanent injunctions and Apple failed to satisfy the requirement, it should not be denied injunctive relief entirely. Rather, relying on the discretion of the district courts in crafting injunctions and the analogous entire market value rule precedent, Apple suggested that the district court could simply structure an injunction to include a "sunset provision" that delays the enforcement until the infringer has had sufficient time to design around the patents. This, Apple proffered, would give meaningful effect to its right to exclude under the patents, while being fair to Samsung, which purported to have design-arounds in process that were not especially onerous. Apple

211. Id. § 32.172 .

212. The Apple I court reached the irreparable harm analysis with respect to the ' 889 patent because it reversed the district court's finding that this patent was likely obvious. 678 F.3d 1314, 1332 (Fed Cir. 2012).

213. Id. at $1321,1328$. 
is correct that the entire market value rule operates to strike a fair balance between the patentee and the infringer. If the infringing product includes many features above and beyond a patented feature, the patentee cannot obtain damages compensation that reaches beyond the value of the patented feature but can still obtain some damages that more appropriately reflect the patented component's market value. For example, if the issue in Apple $v$. Samsung were centered around damages and Apple's patent were directed to an improved smartphone battery, an analogy might be that Apple would be denied damages of two percent of all Samsung's profits per phone-because purchasers do not buy phones for the batteries-but Apple could obtain seven percent of all of Samsung's profits per battery. ${ }^{214}$ This amount is likely less than two percent of profits from the entire phones, but it ensures that Apple is awarded a fair scope of damages that is commensurate with its patent rights.

Similarly, entering an injunction that prevents Samsung's phones from being sold but first allows Samsung a reasonable amount of time to design around the patents strikes a balance that respects Apple's exclusionary patent rights but does not overcompensate it with an injunction that harshly and immediately enjoins all features of a phone where many of those features have nothing to do with the infringement. Indeed, if the patented features and functions at issue do not drive demand and satisfy the nexus test, then the burden on Samsung to design around such features should be relatively small and the design-arounds should have little impact on Samsung's revenues. Samsung's own conduct and evidence showing that Samsung in fact did design around several of Apple's patents suggests this is the case. ${ }^{215}$ However, in the event that the courts take this sunset provision approach, it should be noted that the burden on Apple and other plaintiffs to obtain relief after such an injunction has been entered requires a contempt proceeding and a relatively high burden of proof that the injunction has been violated by clear and convincing evidencethat there is no colorable difference between the new design and the enjoined design. ${ }^{216}$ Although this could potentially lead to a great increase in contempt proceedings and further increase the difficulty of obtaining injunctive relief, the pace of technology advances in areas such as

214. See supra Part IV.

215. See supra Part VI.C.2.

216. See ARRIS Group, Inc. v. SeaChange Int'l Inc., 732 F.3d 1346, 1350 (Fed. Cir. 2013). 
smartphones will often nullify the need for injunctions. New products in such high-tech fields tend to become obsolete or commercially unviable fairly quickly, as occurred with many of Samsung's products by the time a decision on the patent infringement merits was reached.

Ultimately, it is somewhat ironic that the entire market value rule doctrine, the "driving demand" aspect of which makes the nexus test virtually impossible to satisfy, is also the doctrine that may provide a sensible escape hatch for a rule that would otherwise be draconian and inequitable.

The nexus requirement seems to be a strict and inflexible rule that has been applied harshly thus far against patentees to the extent it has not been side-stepped. ${ }^{217}$ The Federal Circuit should be wary of adhering to such rigid rules that are unique to patent cases. In at least three recent landmark patent cases from the Supreme Court, the Supreme Court has flatly rejected tests and analytical frameworks from the Federal Circuit that were viewed as too rigid or patent-specific. In eBay, it was the presumption of irreparable harm. ${ }^{218}$ In KSR International Co. v. Teleflex Inc., it was the "teaching, suggestion, or motivation" test for combining references to show obviousness under 35 U.S.C. $\S 103 .^{219}$ In Bilski v. Kappos, it was the "machine or transformation" test for patent-eligible subject matter under 35 U.S.C. $\S 101 .^{220}$ Given the importance and pervasiveness of the standards for injunctive relief, if the Federal Circuit

217. Aside from Apple, another patentee was recently denied an injunction in part on nexus grounds. In American Beverage Corp. v. Diageo North America, Inc., the patentee asserted a design patent directed to a liquid-containing pouch. $936 \mathrm{~F}$. Supp. $2 \mathrm{~d} 555,567$ (W.D. Pa. 2013). The patentee and the defendant were direct competitors, both using such pouches for their frozen alcoholic beverages. See id. at 568. The patentee's request for a preliminary injunction was denied in part because it failed to show nexus and in fact argued against nexus by claiming that "frozen RTD pouches are impulse purchases made predominantly based upon price and 'appetite appeal,' not the pouch shape." Id. at 616.

218. eBay Inc. v. MercExchange, L.L.C., 547 U.S. 388, 393-94 (2006) (holding that "the [Federal Circuit] erred in its categorical grant of such relief" based on its "'general rule,' unique to patent disputes 'that a permanent injunction will issue once infringement and validity have been adjudged"' (quoting MercExchange, L.L.C. v. eBay Inc., 401 F.3d 1323, 1338 (Fed. Cir. 2005), vacated, 547 U.S. 388)).

219. 550 U.S. 398, 407, 415 (2007) ("We begin by rejecting the rigid approach of the [Federal Circuit]. Throughout this Court's engagement with the question of obviousness, our cases have set forth an expansive and flexible approach inconsistent with the way the [Federal Circuit] applied its TSM test here.").

220. 130 S. Ct. 3218, 3227 (2010) (holding that contrary to the Federal Circuit, "[t]he machine-or-transformation test is not the sole test for deciding whether an invention is a patent eligible 'process.'”). 
does not somehow at least considerably relax the nexus requirement, Apple may become yet another instance where the Supreme Court feels the need to step in and strike down an unduly rigid legal framework.

\section{THE APPLE III FEDERAL CIRCUIT PANEL DECISION PAVES THE WAY FOR EN BANC CONSIDERATION OF THE NEXUS ISSUE}

On November 18, 2013, a three-judge panel at the Federal Circuit issued its decision in Apple III. ${ }^{221}$ The panel held generally that the nexus requirement is here to stay for all injunction decisions, as it "reflects general tort principles of causation equally to the preliminary and permanent injunction contexts."222 The court deemed the nexus test to belong squarely within the irreparable harm analysis, as opposed to any other $e$ Bay factors and to apply with equal force regardless of whether the injunction sought was preliminary or permanent. ${ }^{223}$

As for the post-Apple I and Apple II cases, which decided injunction issues without discussion of nexus, the Apple III panel held that the absence of nexus may be due to the fact that the parties never raised or challenged it. ${ }^{224}$ The panel expressly rejected the idea that simple technology does not implicate the nexus requirement, although complex technology does, holding that "the causal nexus requirement applies regardless of the complexity of the products. It just may be more easily satisfied (indeed, perhaps even conceded) for relatively 'simple' products." 225

The Federal Circuit rejected Apple's suggestion that delayed enforcement of injunctions tailored to infringing features would bring only a more equitable balance to the nexus test. ${ }^{226}$ Although the panel agreed that

221. 735 F.3d 1352 (Fed. Cir. 2013).

222. Id. at 1361.

223. Id. (" $[\mathrm{T}]$ he causal nexus requirement is simply a way of distinguishing between irreparable harm caused by patent infringement and irreparable harm caused by otherwise lawful competition - e.g., 'sales that would be lost even if the offending feature were absent from the accused product.' Apple I, 678 F.3d at 1324. The former type of harm may weigh in favor of an injunction, whereas the latter does not."); id. at 1362-63 (disagreeing with Apple that "there are significant differences between preliminary and permanent injunctions that make the causal nexus unjustified and unnecessary for permanent injunctions").

224. Id. at 1362.

225. Id.

226. Id. at 1363. 
delayed enforcement of injunctions can be equitable in general, there was no reason to allow delayed enforcement only for permanent injunctions, and absent proof of nexus to irreparable harm in the first place, no injunction - delayed or otherwise - would be appropriate. ${ }^{227}$

Although the panel rejected Apple's attempt to do away with the nexus requirement entirely, it did "agree with Apple that certain standards arguably articulated by the district court go too far." ${ }^{228}$ The Apple III panel generally approved of the district court's insistence that proof of nexus be tied to the patented inventions and designs. ${ }^{229}$ But the Federal Circuit purported to scale back the test, which it referred to as "rigid" and "categorical," as follows:

However, these principles do not mean Apple must show that a patented feature is the one and only reason for consumer demand. Consumer preferences are too complex - and the principles of equity are too flexible - for that to be the correct standard. Indeed, such a rigid standard could, in practice, amount to a categorical rule barring injunctive relief in most cases involving multi-function products, in contravention of eBay. See eBay, 547 U.S. at 393, 126 S. Ct. 1837 (rejecting "expansive principles suggesting that injunctive relief could not issue in a broad swath of cases").230

Thus, the court relaxed the nexus test in three important respects that are inconsistent with the test articulated in Apple I and Apple II.

First, the Apple III panel backed off of the idea that to prove nexus one must show that the patented feature is the basis for customer demand for the infringing product:

$[R]$ ather than show that a patented feature is the exclusive reason for consumer demand, Apple must show some connection between the patented feature and demand for Samsung's products. There might be a variety of ways to make this required showing, for example, with evidence that a patented feature is one of several features that cause consumers to make their purchasing decisions. It might also be shown with evidence that the inclusion of a patented feature makes a product significantly more desirable. Conversely, it might be shown with evidence that the absence of a patented feature would make a product significantly less desirable. ${ }^{231}$

This "some connection" test is substantially weaker than, and flatly inconsistent with, the plain text of Apple II, which required the patented

227. Id. ("[T]he purpose of the causal nexus requirement is to show that the patentee is irreparably harmed by the infringement. Without such a showing, it is reasonable to conclude that a patentee will suffer the same harm with or without an injunction, thus undermining the need for injunctive relief in the first place.").

228. Id. at 1364

229. Id. ("[T]his inquiry should focus on the importance of the claimed invention in the context of the accused product, and not just the importance, in general, of features of the same type as the claimed invention.").

230. Id.

231. Id. (emphasis added). 
feature to "drive[] consumer demand for the accused product.",232 Moreover, the Federal Circuit in Apple III used the same laptop battery analogy but to reach a different conclusion. In Apple II, the Federal Circuit held that " $[\mathrm{t}]$ he causal nexus requirement is not satisfied simply because removing an allegedly infringing component [for example, a battery] would leave a particular feature, application, or device less valued."'233 In Apple III, however, the panel said,

[I]f a particular patented laptop battery lasts significantly longer than any other battery on the market, then the replacement of that battery with a noninfringing battery might make a laptop less desirable. In that case, it might be reasonable to conclude that the patented battery is a driver of consumer demand for the laptop. ${ }^{234}$

These statements are plainly inconsistent - the removal of a feature shows a lack of value that either can or cannot prove nexus. Apple II required affirmative proof of nexus, but now Apple III seems to accept negative proof that absence of the features at issue affects demand. In doing so, Apple III seems to have adopted the very reasoning it reversed in Apple II.

Second, although the Federal Circuit in Apple I and Apple II consistently analyzed nexus one patented feature at a time, the Apple III panel agreed with Apple that consideration of multiple infringed patents together is appropriate:

While it is true that this court analyzed causal nexus on a patent-by-patent basis in Apple I, we did not mean to foreclose viewing patents in the aggregate. Rather, we believe there may be circumstances where it is logical and equitable to view patents in the aggregate. For example, it may make sense to view patents in the aggregate where they all relate to the same technology or where they combine to make a product significantly more valuable. To hold otherwise could lead to perverse situations such as a patentee being unable to obtain an injunction against the infringement of multiple patents covering different-but when combined, all-aspects of the same technology, even though the technology as a whole drives demand for the infringing product. 235

This sudden adoption of an aggregate nexus standard raises more questions than it answers, but the panel "leave[s] it to the district court . . . to address this issue in the first instance on remand." 236 For example, what are the

232. Apple II, 695 F.3d 1370, 1375 (Fed. Cir. 2012).

233. Id. at 1376.

234. Apple III, $735 \mathrm{~F} .3 \mathrm{~d}$ at $1364-65$.

235. Id. at 1365 .

236. Id. 
"circumstances" when it is appropriate to aggregate patents for the nexus inquiry? Is it enough that the patented features are all useful and embodied in the same accused product to say that they "combine to make a product significantly more valuable"? In this case, looking at Apple's infringed patents in the context of Samsung's products, more guidance on when aggregation is appropriate would have been tremendously helpful.

Third, the Apple III panel believed that Apple's survey evidence showing the price premium that consumers would pay for certain features in a smartphone should not have been discarded by the district court as irrelevant, and it remanded to the district court to reconsider that survey evidence. $^{237}$ This view of the survey evidence is in considerable tension with the Federal Circuit's prior pronouncement in Apple II that " $[\mathrm{t}] \mathrm{o}$ establish a sufficiently strong causal nexus, Apple must show that consumers buy the Galaxy Nexus because it is equipped with the apparatus claimed in the '604 patent." ${ }^{, 238}$ To prove that a consumer finds a feature valuable is not the same as proving that the feature is the reason consumers buy the product.

The Federal Circuit rule is that prior panel decisions govern over later decisions that are inconsistent with those earlier decisions, unless the earlier decisions are overruled en banc. ${ }^{239}$ Thus, Apple I and Apple II are controlling over Apple III where Apple III is inconsistent with the earlier panel decisions, unless and until the en banc court overrules its prior decisions.

This case, directed at the heart of the patent system - the right of a patentee to exclude infringers - presents an exceptionally important issue where the above-noted inconsistencies would tend to make en banc consideration likely. ${ }^{240}$ Indeed, because the same panel of judges decided Apple I and Apple III, only five of eighteen active Federal Circuit judges

237. Id. at 1368 ("[W]e see no reason why, as a general matter of economics, evidence that a patented feature significantly increases the price of a product cannot be used to show that the feature drives demand for the product. This is not to suggest that consumers' willingness to pay a nominal amount for an infringing feature will establish a causal nexus. For example, consumers' willingness to pay an additional $\$ 10$ for an infringing cup holder in a $\$ 20,000$ car does not demonstrate that the cup holder drives demand for the car. The question becomes one of degree, to be evaluated by the district court. Here, the district court never reached that inquiry because it viewed Dr. Hauser's survey evidence as irrelevant.").

238. Apple II, 695 F.3d at 1376.

239. Newell Cos. v. Kenney Mfg., 864 F.2d 757, 765 (Fed. Cir. 1988) (holding that where there is a conflict among Federal Circuit precedential decisions, the rule is that the earlier panel decision controls unless overruled en banc).

240. See FED. CIR. R. 35 (providing that en banc hearing of a case is appropriate when the issues raised by the case are of exceptional importance or where en banc consideration is necessary to ensure uniformity of the court's precedent). 
have weighed in on the nexus issue. ${ }^{241}$ Other judges, for example those in Douglas Dynamics, have addressed the irreparable harm requirement without application of the nexus requirement, further compounding the tension within the Federal Circuit on the entire irreparable harm prong for injunctive relief. ${ }^{242}$ A matter of such importance to the patent system is worthy of the entire court's attention and consideration. Many amici on both sides of the issue will likely encourage the Federal Circuit to take up the nexus issue en banc.

As discussed above, the outcome of Apple III was a remand to the district court for further consideration under a modified nexus standard. On remand, the district court denied Apple's renewed request for a permanent injunction, finding the price premium survey evidence unconvincing and viewing the aggregated effect of Apple's infringed patents insufficient to show nexus. ${ }^{243}$ Apple has appealed that decision. ${ }^{244}$ Thus, the nexus issue now appears to be teed up for Apple's fourth bite at the apple.

241. Apple I and Apple III were decided by Judges Bryson, Prost, and O'Malley. Apple I, 678 F.3d 1314, 1316 (Fed. Cir. 2012); Apple III, 735 F.3d at 1355. Apple II was decided by Judges Prost, Moore, and Reyna. Apple II, 695 F.3d at 1372; see also The Court: Judges, U.S. CT. APPEALS FOR FED. CIR., http://www.cafc.uscourts.gov/judges (last visited Apr. 18, 2014) (listing the Federal Circuit's eighteen judges).

242. Douglas Dynamics, LLC v. Buyers Products Co. was decided by Chief Judge Rader and Judges Newman and Mayer. 717 F.3d 1336, 1338 (Fed. Cir. 2013). In a later decision, Chief Judge Rader, along with Judges Lourie and Wallach, found irreparable harm although acknowledging but not applying the nexus requirement, holding that "[a]s direct competitors in a limited market, Broadcom's harm was clearly linked to Emulex's infringement of Broadcom's patent property rights." Broadcom Corp. v. Emulex Corp., 732 F.3d 1325, 1337 (Fed. Cir. 2013).

243. Apple, Inc. v. Samsung Elecs. Co., No. 11-CV-01846-LHK, 2014 WL 976898 (N.D. Cal. Mar. 6, 2014).

244. Apple Inc.'s Notice of Cross Appeal, Apple, Inc. v. Samsung Elecs. Co., No. 11-CV-01846-LHK (N.D. Cal. Mar. 11, 2014), ECF No. 3026. 


\section{CONCLUSION}

The concept of a nexus requirement has some legitimate policy concerns behind it. It seems unfair to enjoin an entire product when only a small part of the product infringes a patent. However, to insist that this consideration factors only into the irreparable harm analysis, or to elevate the nexus requirement above the $e B a y$ factors, is too rigid an application of an otherwise sensible concept. To the extent the nexus requirement remains good law, considerations of nexus best belong in the balance of the hardships and public interest factors where there is greater flexibility for courts to weigh the equities.

If nexus continues to be required to prove irreparable harm, the public needs guidance of more than what will not suffice to prove nexus, but what will. Presently, the type of evidence that seems to be required may well preclude injunctive relief in the vast majority of cases that otherwise justify an injunction, hence the apparent reluctance to strictly follow the nexus precedent among the post-Apple decisions. And there is no good reason to limit the nexus analysis to a patent-by-patent consideration. If the same product is infringed by multiple patents and those patented features together drive demand and cause the patentee to lose sales, the nexus test should be deemed satisfied.

At a minimum, the entire market value rule doctrine that set us down the path of the nexus requirement should be taken in full and not simply for the disembodied notion of a patented feature driving demand. The entire market value rule is not a bar to damages but a means to scale back damages as appropriate and fair under the circumstances of the case. Likewise, the failure to satisfy the nexus requirement should not be a complete bar to injunctive relief when the equities otherwise would justify an injunction. The scope of the injunction should instead be tailored in a way that is appropriate and fair-enjoin the infringing feature, not the product, and delay the enforcement of the injunction for a reasonable time period to allow the infringer to design around that feature. 